\title{
阿武隈川水系における放射性セシウムの数値シミュレーション
}

\author{
石 川 百合子*n \\ 保 高 徹 生*** \\ 川 智 哉**
東 野 晴 行*
}

\section{Estimation of Concentration of Radioactive Cesium in Abukuma River Basin Using Numerical Simulation}

\author{
Yuriko ISHIKAWA ${ }^{*, n}$, Tomoya KAWAGUCHI**, \\ Tetsuo YASUTAKA*** and Haruyuki HIGASHINO*
}

\footnotetext{
* The Research Institute of Science for Safety and Sustainability, National Institute of Advanced Industrial Science and Technology, Onogawa 16-1, Tsukuba, Ibaraki 305-8569, Japan

** Nihon Suido Consultants Co., Ltd (NSC), 22-1 Nishi-Shinjuku 6-Chome, Shinjuku-ku, Tokyo 163-1122, Japan

*** Institute for Geo-Resources and Environment, National Institute of Advanced Industrial Science and Technology, 1-1-1 Higashi, Tsukuba, Ibaraki 305-8567, Japan
}

\begin{abstract}
In order to assess the concentrations of radioactive substances in river basins contaminated by such substances released through the Fukushima Daiichi nuclear power plant accident in March 2011, a watershed model was developed. The model, improved on the basis of the AIST-SHANEL software, can estimate indexes such as the river water concentration and deposition amount of radioactive cesium in river basins after the accident using a submodel for estimating suspended solids and the radioactive cesium load in runoff water. In this study, we carried out some case studies by applying the model to the Abukuma River basin. Two major results were obtained. The model was valid for the estimation of the concentration of radioactive cesium, and the radioactive cesium load in the runoff water was quite low. In particular, for cesium 137, its natural elimination rate is low owing to its long half-life. As a result, the deposition amount of radioactive cesium in river basins would only negligibly decrease. Therefore, we suggest a need for the comprehensive examination of all measures of reducing radioactive cesium including decontamination. The model is useful for evaluating the temporal-spatial concentrations of and the impact of control policies for radioactive substances in river basins associated with nuclear accidents.
\end{abstract}

Keywords: Watershed model; Radioactive cesium; River water concentration; Dissolved matter; Particle sorbed matter; Deposition amount; Abukuma river basin

\section{1.はじめに}

2011 年の東日本大震災に伴う福島第一原発事故によ り放出された放射性物質が広範囲に拡散したことによる 影響が懸念されている。原発事故により放出された放射 性物質のうち，河川流域全体で問題となるのは，環境中 への放出量が多く，広範囲に拡散され，かつ半減期が長 い放射性セシウムである。これには半減期が約 2.1 年の セシウム 134 と半減期が約 30 年のセシウム 137 の 2 つ がある。放射性セシウムは土壤粒子に吸着しやすい性質 が知られており ${ }^{1 \sim 5)}$ ，原発事故後においても土壤に沈着 した放射性セシウムは表層から $5 \mathrm{~cm}$ 以内の媣さにその 殆どが存在していることが確認されている ${ }^{6)}$ 。大気中で 広範囲に拡散した放射性物質は風雨によって流域土壤に
沈着した後, 降水による出水に伴って流域から河川等を 経由して海域へ流出するものの, その多くは依然として 流域に残存している状況にある7

この状況下，流域における放射性物質の実態を把握す るため, 主に晴天時を対象にした調査として, 独日本原 子力研究開発機構 (JAEA) は福島県内の河川 50 箇所を 対象に平成 23 年 6 月から 12 月までに 3 回の調査 ${ }^{6)}$ を, 環境省は福島県, 岩手県, 宮城県をはじめ関東地方の各 都県内における公共用水域を対象に平成 23 年 6 月から 数ヶ月に 1 回程度の調査 ${ }^{8)}$, それぞれ実施している。 一方，放射性セシウムの出水時における観測の必要性 が指摘されている。村上 ${ }^{9)}$ は(独)日本原子力研究開発機構 $(\mathrm{JAEA})^{6)}$ の議論に基づき，放射性セシウムの大部分は 眯濁物質に由来していること, 䋰濁物質の大部分は降水

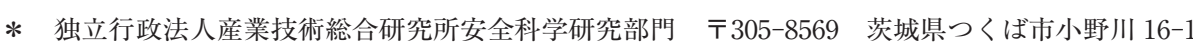

** 株式会社日水コン環境事業部環境・資源部 † 163-1122 東京都新宿区西新宿 6-22-1 新宿スクエアタワー

*** 独立行政法人産業技術総合研究所地圈資源環境研究部門 $\bar{\top} 305-8567$ 荻城県つくば市東 1-1-1 中央第 7

ๆ＼cjkstart連絡先：y-ishikawa@aist.go.jp 
に伴う出水にもたらされることを示している。長尾 ${ }^{10)}$ と 中村ら ${ }^{11)}$ は阿武隈川中流において 2011 年 5 月から 2012 年 8 月まで観測を実施し, 河川流量が増加する出水時に セシウム 137 の河川水濃度が増加すること, 全濃度に占 める㲘濁態濃度の割合が $100 \%$ 程度になることを示して いる。また，流域における放射性セシウムの蓄積量の実 態調查として, 文部科学省放射線量等分布マップ拡大サ イト ${ }^{12)}$ が公表されている。このように, 放射性セシウム に係る観測を時間的, 空間的に詳細に実施する必要性が 示されているものの, これを実施することは, 作業に要 する労力や費用が膨大となることから極めて困難である と思われる。

この問題を解決するには放射性セシウムの河川水濃度 を時間的, 空間的に推定できる解析モデルを用いた予測 が有効であろう。流域土壇に沈着した後, 降水による出 水に伴って掃流される放射性セシウムは溶存態および懸 濁態の状態で存在し，さらに環境媒体中の㲘濁物質の割 合に応じて溶存態と懸濁態に再分配される。このうち, 溶存態の放射性セシウムは植物に吸収されやすく移動性 が高いという特性があることから，放射性セシウムの総 量のみならず存在形態も把握することが重要である。流 域を対象とした放射性物質の動態モデルに関して，佐 藤 ${ }^{13)}$ は対象場が放射性物質の暴露を受けたとき, 大気, 水, 土壤等の各相への放射性物質の分配の状態を把握す るための集中型モデルが多いこと, このモデルを発展さ せた移流拡散を基礎とした分布型モデルに関しては性能 評価が十分でないことを指摘している。このように，流 域における放射性セシウムをはじめ放射性物質の動態を 時間的, 空間的に密な解像度でかつ性能保証できるモデ ルは今のところ極めて少ないものと考えられる。

これまで, (独)産業技術総合研究所は産総研 - 水系暴 露解析モデル (AIST-SHANEL) ${ }^{14)}$ を開発し, 現在では 日本全国 109 の 1 級水系を 3 次メッシュ（約 $1 \mathrm{~km}$ 格 子）によりモデル化し, 月単位における対象物質の河川 水濃度を推定できるモデルを公開している ${ }^{15,16)}$ 。AISTSHANEL は流域の蒸発散量や積雪融雪量等を推定する 熱収支解析，主に河川における流量等を推定する流れ解 析, 水温や懸濁物質の濃度を推定する水質解析, そして 対象物質の河川水濃度を推定する物質動態解析の 4 つの サブモデルから構成される。物質動態解析は移流拡散だ けでなく, 対象物質の懸濁物質への吸着の他, 沈降や 再浮上等の物質動態を考慮している。本研究では AISTSHANEL をプラットフォームとして, 時間解像度を日 単位としたうえで流域における懸濁物質の流出ポテン シャルと，環境媒体中の懸濁物質の割合に応じた放射性 物質の存在形態を考慮すべく，流域における放射性物質 を対象にした堆積負荷掃流モデルを追加し，阿武隈川水 系を対象にケーススタディーを実施する。以下，放射性 セシウムの流域における蓄積量の残存状況や河川水濃度 の推定に関する妥当性を検証するとともに，その蓄積量 を減少させる要因を分析する。

2. 放射性セシウムの動態解析モデル

\section{1 流域における堆積負荷掃流モデル \\ 2.1.1 懸濁物質・水分配係数の導入}

本研究では, 流域における放射性セシウムの動態を流
域土壤から流出した後の放射性セシウムは環境媒体中の 懸濁物質の割合に応じて溶存態, 懸濁態に再分配される こと, 放射性セシウムは流出水において, 水と懸濁物質 以外には分配されないこと, 風による飛散や除染は考慮 しないことを仮定して定式化を図った。

いま, 流出水における溶存態の物質濃度を $C w\left(\mathrm{~Bq} \cdot \mathrm{m}^{-3}\right)$, 懸濁態の物質濃度を $C s\left(\mathrm{~Bq} \cdot \mathrm{m}^{-3}\right)$ とする。ここで, 流 出水における溶存態分配率 $f w(-)$ は容積 $V w\left(\mathrm{~m}^{3}\right)$ を 用いて次式で定義される。ただし, 懸濁態成分による流 出水容積の増加はないものと仮定する。

$$
f w=\frac{C w V w}{C w V w+C s V w} \cdots \cdots \cdots \cdots \cdots \cdots \cdots \cdots \cdots \cdots \cdots \cdots \cdots \cdot 1
$$

また, 流出水では溶存態成分と懸濁態成分とは分配平衡 であるとすると，次式を得る。

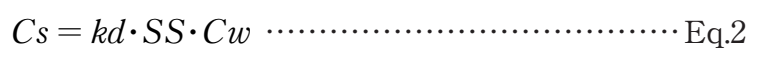

ここで, $k d$ : 懸濁物質・水分配係数 $\left(\mathrm{m}^{3} \cdot \mathrm{g}^{-1}\right), S S$ : 懸 濁物質の濃度 $\left(\mathrm{g} \cdot \mathrm{m}^{-3}\right)$ である。

Eq.1に Eq.2 を代入すると, 次式を得る。

$$
\begin{aligned}
& f w=\frac{C w V w}{C w V w+C s V w} \\
& =\frac{C w V w}{C w V w+(k d \cdot S S) C w V w}=\frac{1}{1+k d \cdot S S} \cdots \text { Eq.3 }
\end{aligned}
$$

一方, 懸濁態分配率 $f_{s}$ は次式となる。

$$
f s=1-f w=\frac{k d \cdot S S}{1+k d \cdot S S} \cdots \cdots \cdots \cdots \cdots \cdots \cdots \cdots \cdots \cdots \cdot \text { Eq.4 }
$$

Eq.4 から $k d$ が 0 のとき $f s$ は 0 となり, $k d$ が非常に大き いとき $f s$ は 1 に漸近する。

\subsection{2 堆積負荷掃流モデル}

放射性セシウムの発生源は大気から土壌に降下した沈 着量のみであり, 沈着量を蓄積量とした初期条件とした 堆積負荷掃流型の物質収支式とした。ここでは, 放射性 セシウムの流出負荷量は土壤における蓄積量と流出量の 1 乗, すなわち線形に応答すると仮定し, さらに㲘濁物質 の濃度に応じて流出負荷量も変化するように定式化した。

$$
\begin{aligned}
& \frac{d S}{d t}=-k f \cdot f s \cdot S \cdot q-k r \cdot S \cdots \ldots \ldots \ldots \ldots \ldots \ldots \ldots \ldots \ldots \ldots \ldots+\text { Eq.5 }
\end{aligned}
$$

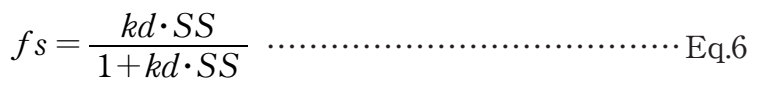

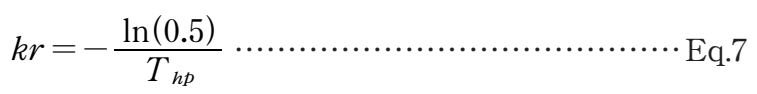

ここに, $S$ : 蓄積量 $\left(\mathrm{Bq} \cdot \mathrm{m}^{-2}\right), k f$ : 負荷流出係数 $\left(\mathrm{m}^{-2}\right)$, $f_{s}$ : 矁濁態分配率 $(-), q$ : 流出量 $\left(\mathrm{m}^{2} \cdot \mathrm{s}^{-1}\right), k r$ : 消失 速度 $\left(\mathrm{s}^{-1}\right), T_{h p}$ : 半減期 $(\mathrm{s})$ である。

\section{2 河道における一次元移流拡散モデル}

ここでは, AIST-SHANEL の物質収支式 ${ }^{14)}$ に基づき, 流出水における放射性セシウムの環境動態を考慮して懸 濁物質および放射性セシウムの物質収支を定式化した。 


\section{2.1 懸濁物質の収支式}

河川水と河川底泥層との物質移動は, 河川に流入した 懸濁物質が沈降したものが支配的であると仮定し，河川 底泥層の厚さは懸濁物質の挙動から決定できるとした。 次式は懸濁物質の収支を示したものである。

$$
\begin{aligned}
& \frac{\partial}{\partial t}(A r C s s)+\frac{\partial}{\partial x}(A r U r C s s) \\
& =\frac{\partial}{\partial x}\left(A r D r \frac{\partial C s s}{\partial x}\right)-W \frac{A r}{H r}+G \frac{A r}{R}+f s s, \\
& f s s=\frac{\alpha_{s s}(q r b l)^{\beta_{s s}}}{b l}, D r=5.93 H r u^{*} \text { (Elderの縦分散倸数), } \\
& \frac{d F s s}{d t}=W \frac{A r}{H r}-G \frac{A r}{R}
\end{aligned}
$$

河川底泥厚の值は次式によって決定した。

$$
\left(\begin{array}{l}
H r_{s d w} \\
H r_{s d s}
\end{array}\right)=\left(\begin{array}{c}
\frac{w c}{(1-w c) \rho_{s d w}} \\
\frac{1}{\rho_{s d s}}
\end{array}\right) \frac{F s s}{\left(\frac{A r}{R}\right)} \ldots \ldots \ldots \ldots \ldots \ldots \ldots \ldots \ldots . .9
$$

懸濁物質の沈降および再浮上の定数に関しては, 以下の ように設定した。

$$
\begin{aligned}
& \left(\begin{array}{c}
W \\
G
\end{array}\right)=\left(\begin{array}{c}
0 \\
G_{s s}\left(\frac{u^{* 2}}{u_{c}^{* 2}}-1\right)^{m_{s s}}
\end{array}\right) \text { when } u^{*} \geq u_{c}^{*}, \\
& \left(\begin{array}{c}
W \\
G
\end{array}\right)=\left(\begin{array}{c}
w C s s \\
0
\end{array}\right) \text { when } u^{*} \leq u_{c}^{*}, u^{*}=\sqrt{g R I e}, \\
& w=\frac{g\left(\rho_{s d s}-\rho_{s d w}\right) d_{s s}^{2}}{18 \mu} \text { (Stokes式による沈降速度) } \cdots \cdots \text { Eq.10 }
\end{aligned}
$$

ここに, $A r$ : 流水断面積 $\left(\mathrm{m}^{2}\right), C s s$ : 䀣濁物質の河川 水濃度 $\left(\mathrm{g} \cdot \mathrm{m}^{-3}\right), U r$ : 断面平均流速 $\left(\mathrm{m} \cdot \mathrm{s}^{-1}\right), D r$ : 縦 分散係数 $\left(\mathrm{m}^{2} \cdot \mathrm{s}^{-1}\right), H r$ : 平均水深 $(\mathrm{m}), R$ : 径深 $(\mathrm{m})$, $f_{s s}$ : 斜面からの横流入負荷量 $\left(\mathrm{g} \cdot \mathrm{m}^{-1} \cdot \mathrm{s}^{-1}\right), F s s$ : 河川底 泥の堆積負荷量 $\left(\mathrm{g} \cdot \mathrm{m}^{-1}\right), u^{*}$ : 摩擦速度 $\left(\mathrm{m} \cdot \mathrm{s}^{-1}\right), u_{c}{ }^{*}$ : 限界摩擦速度 $\left(\mathrm{m} \cdot \mathrm{s}^{-1}\right), g$ : 重力加速度 $\left(\mathrm{m} \cdot \mathrm{s}^{-2}\right), I e$ : 動水勾配 (-), $G_{S S}$ : 河川底泥からの再浮上速度定数 $\left(\mathrm{g} \cdot \mathrm{m}^{-2} \cdot \mathrm{s}^{-1}\right), m_{S S}$ : 河川底泥からの再浮上定数 $(-), w$ : 懸濁物質の沈降速度 $\left(\mathrm{m} \cdot \mathrm{s}^{-1}\right), w c$ : 河川底泥の含水率 $(-)$, $\rho_{s d s}$ : 眯濁物質の密度 $\left(\mathrm{g} \cdot \mathrm{m}^{-3}\right), \rho_{s d w}$ : 媒体の密度 $\left(\mathrm{g} \cdot \mathrm{m}^{-3}\right)$, $d_{S S}$ : 懸濁物質の代表粒径 $(\mathrm{m}), \mu$ : 粘性係数 $\left(\mathrm{g} \cdot \mathrm{m}^{-1} \cdot \mathrm{s}^{-1}\right)$, $\alpha_{S S}$ および $\beta_{S S}$ : 定数, $q r$ : 横流入量 $\left(\mathrm{m}^{2} \cdot \mathrm{s}^{-1}\right), b l$ : 河道 長（m）である。

2. 2.2 放射性セシウムの収支式

次式は放射性セシウムの収支を示したものである。

$$
\begin{aligned}
& \frac{\partial}{\partial t}\left(A r C r_{w}\right)+\frac{\partial}{\partial x}\left(A r U r C r_{w}\right) \\
& =\frac{\partial}{\partial x}\left(A r D r \frac{\partial C r_{w}}{\partial x}\right)+W r \frac{A r}{H r}+G r \frac{A r}{R} \\
& +D_{s d 1}-K_{w} A r C r_{w}+f r
\end{aligned}
$$

$$
\begin{aligned}
& \left(\frac{d\left(\frac{A r}{R} H r_{s d w} C r_{s d w}\right)}{d t}\right)=-\left(\begin{array}{c}
D_{s d 1} \\
G r \frac{A r}{R}+W r \frac{A r}{H r}
\end{array}\right) \\
& +\left(\begin{array}{c}
D_{s d 2} \\
-D_{s d 2}
\end{array}\right)-\left(\begin{array}{l}
\left.K_{s d w} \frac{A r}{R} H r_{s d s} C r_{s d s}\right) \\
K_{s d s} \frac{A r}{R} H r_{s d w} C r_{s d w}
\end{array}\right)
\end{aligned}
$$

河川水と河川底泥間における拡散移動, 沈降および再浮 上は次式による。

$$
\begin{aligned}
& \left(\begin{array}{c}
W r \\
G r \\
D_{s d 1}
\end{array}\right)=\left(\begin{array}{c}
0 \\
\frac{G}{\rho_{s d s}} C r_{s d s} \\
0
\end{array}\right) \text { when } u^{*} \geq u_{c}^{*},\left(\begin{array}{c}
W r \\
G r \\
D_{s d 1}
\end{array}\right) \\
& =\left(\begin{array}{c}
0 \\
-W C r_{w} f s \\
-U_{w, s d w} \frac{A r}{H r}\left(C r_{w}-\frac{H r}{R} \frac{C r_{s d w}}{H_{s d w, w}}\right)
\end{array}\right) \text { when } u^{*}<u_{c}^{*}, \\
& f_{s}=\frac{k d \cdot S S}{1+k d \cdot S S}, \frac{1}{U_{w, s d w}}=\frac{1}{u_{w}}+\frac{H_{w, s d w}}{u_{s d w}}, \\
& H_{s d w, w}=k d \rho_{s d w}, H_{w, s d w}=\frac{1}{k d \rho_{s d w}} \quad \cdots \ldots \ldots \ldots . . . . .13
\end{aligned}
$$

河川底泥液相と固相間の拡散移動は河川底泥固相からの 再浮上が生ずるような規模の大きな出水時では生じない ものと仮定した。

$$
\begin{aligned}
& D_{s d 2}=\left(\begin{array}{c}
0 \\
-U_{s d w, s d s} \frac{A r}{R}\left(C r_{s d w}-\frac{C r_{s d s}}{H_{s d s, s d w}}\right)
\end{array}\right) \\
& \text { when } u^{*}\left(\begin{array}{c}
\geq u_{c}^{*} \\
<u_{c}^{*}
\end{array}\right), \frac{1}{U_{s d w, s d s}}=\frac{1}{u_{s d w}}+\frac{H_{s d w, s d s}}{u_{s d s}}, \\
& H_{s d s, s d w}=k d \rho_{s d s}, H_{s d w, s d s}=\frac{1}{k d \rho_{s d s}} \cdots \cdots \cdots \cdots . . .
\end{aligned}
$$

ここに, $C r$ : 濃度 $\left(\mathrm{g} \cdot \mathrm{m}^{-3}\right), f r$ : 斜面からの横流入負荷 量 $\left(\mathrm{g} \cdot \mathrm{m}^{-1} \cdot \mathrm{s}^{-1}\right), \rho_{s d s}$ : 懸濁物質の密度 $\left(\mathrm{g} \cdot \mathrm{m}^{-3}\right), K$ : 消 失速度定数 $\left(\mathrm{s}^{-1}\right), k d$ : 懸濁物質 - 水分配係数 $\left(\mathrm{m}^{3} \cdot \mathrm{g}^{-1}\right)$, $U$ : 移動速度定数 $\left(\mathrm{m} \cdot \mathrm{s}^{-1}\right), u$ : 移動係数 $\left(\mathrm{m} \cdot \mathrm{s}^{-1}\right), H$ : 分配平衡定数 $(-), w$ : 河川水を表す添字, $s d w$ ：河川 底泥液相を表す添字, $s d s$ : 河川底泥固相を表す添字, $f_{s}$ : 流出水における懸濁態分配率 $(-)$ である。

3. ケーススタディー

ここでは, 阿武隈川水系を対象として, 主に河川流量 ならびに放射性セシウムの流域における蓄積量および河 川水濃度を溶存態と懸濁態毎に推定し，これらを観測值 と比較することにより，本モデルの妥当性を検証した。 対象物質はセシウム 134 とセシウム 137 とした。気象 


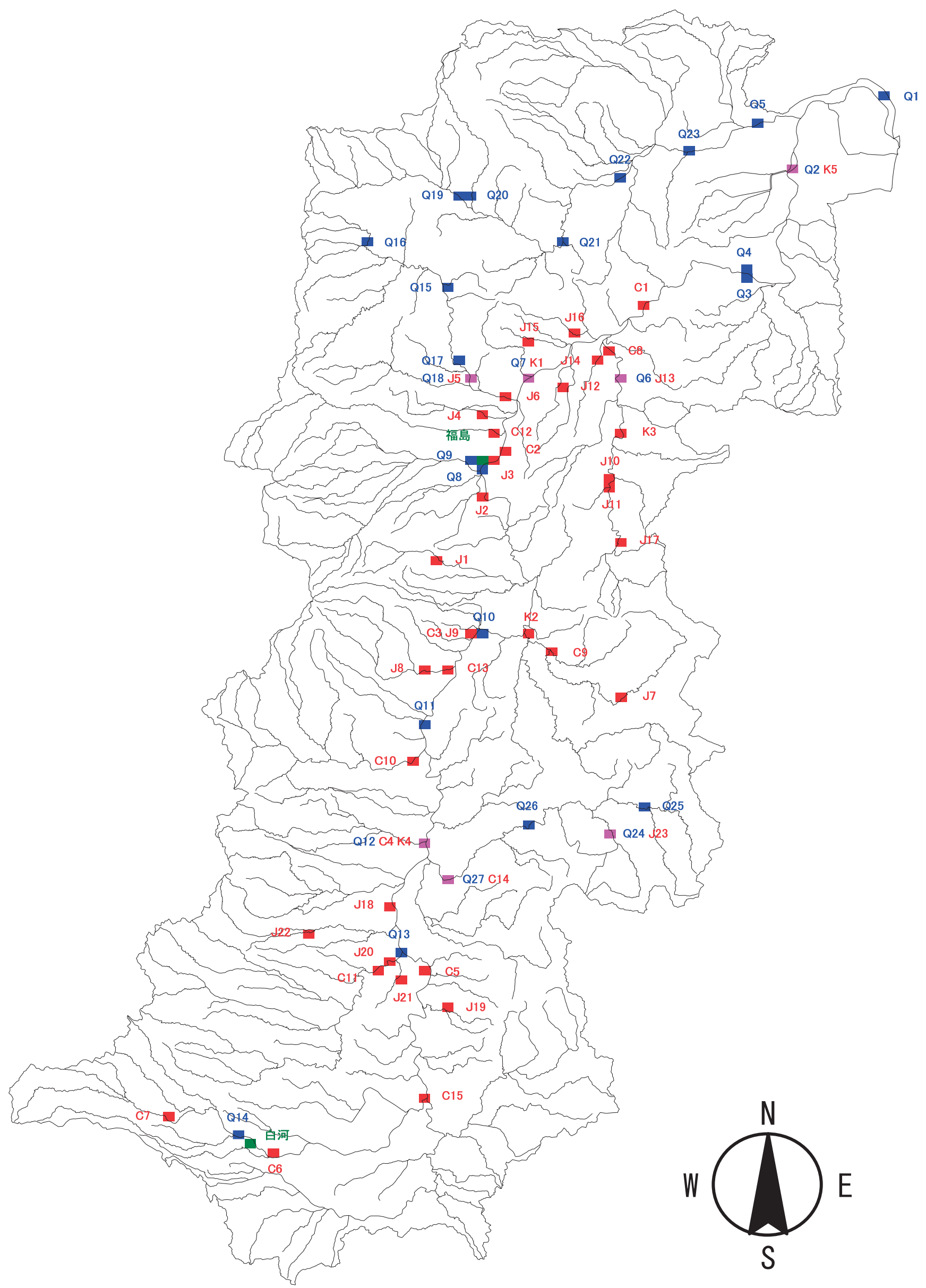

図1阿武隈川水系における観測地点位置図

注) 気象官署 $\left(\right.$ 気象庁 ${ }^{17}$ : 福島, 白河) 流量 (国土交通省 ${ }^{18}: \mathrm{Q} 1 \sim \mathrm{Q} 27$ ), 放射性セシウムの河川水濃度 $\left(\mathrm{JAEA} \mathrm{A}^{6}: \mathrm{J} 1 \sim \mathrm{J} 23\right.$, 環境省 ${ }^{8}$ : $\mathrm{K} 1 \sim \mathrm{K} 5$, Yasutaka et al. $\left.{ }^{22)}: \mathrm{C} 1 \sim \mathrm{C} 15\right)$ 
表 1 解析目的別の対象期間

\begin{tabular}{|c|c|c|c|c|c|}
\hline \multirow{2}{*}{ 解析の内容 } & 2008 & 2009 & 2010 & 2011 & 2012 \\
\cline { 2 - 6 } & 12 月 & 1 12月 & 12 月 & 1 12月 & $1 \sim 12$ 月 \\
\hline 熱収支解析 & キャリブレーション & \multicolumn{3}{|c|}{ 検証 } \\
\hline 流れ解析 & キャリブレーション & \multicolumn{3}{|c|}{ 検証 } \\
\hline 水質解析 & - & - & \multicolumn{3}{|c}{ 検証 } \\
\hline 物質動態解析 & - & - & \multicolumn{3}{c|}{ 検証 } \\
\hline
\end{tabular}

表2 Yasutaka et al. ${ }^{22)}$ の観測值に基づく懸濁物質・水分配係数 $\mathrm{kd}$ の設定

\begin{tabular}{|c|c|c|c|c|c|c|c|c|c|c|c|c|c|c|c|c|c|c|}
\hline \multirow[t]{2}{*}{ 観測地点 } & \multirow{2}{*}{$\begin{array}{c}\text { 懸濁物質 } \\
\mathrm{mg} \cdot \mathrm{L}^{-1}\end{array}$} & \multicolumn{3}{|c|}{$\mathrm{D}$ : 溶存態濃度 $\mathrm{Bq} \cdot \mathrm{L}^{-1}$} & \multicolumn{3}{|c|}{$\mathrm{P}$ :懸濁態濃度 $\mathrm{Bq} \cdot \mathrm{L}^{-1}$} & \multicolumn{3}{|c|}{$\mathrm{T}$ : 全濃度 $\mathrm{Bq} \cdot \mathrm{L}^{-1}$} & \multirow[t]{2}{*}{$\mathrm{D} / \mathrm{T}$} & \multicolumn{3}{|c|}{ 懸濁態中濃度 Bq·kg ${ }^{-1}$} & \multicolumn{2}{|c|}{ 134Cs: kd } & \multicolumn{2}{|c|}{ 137Cs: kd } \\
\hline & & $134 \mathrm{Cs}$ & $137 \mathrm{Cs}$ & 合計 & $134 \mathrm{Cs}$ & 137Cs & 合計 & 134Cs & $137 \mathrm{Cs}$ & 合計 & & 134Cs & $137 \mathrm{Cs}$ & 合計 & ${\mathrm{L} \cdot \mathrm{kg}^{-1}}^{-1}$ & $\mathrm{~L} \cdot \mathrm{mg}^{-1}$ & $\mathrm{~L} \cdot \mathrm{kg}^{-1}$ & $L \cdot \mathrm{mg}^{-1}$ \\
\hline $\mathrm{C} 1$ & 6.0 & 0.024 & 0.044 & 0.068 & 0.075 & 0.126 & 0.202 & 0.099 & 0.170 & 0.270 & $25 \%$ & 12500 & 21000 & 33500 & $5.2 \mathrm{E}+05$ & 0.52 & $4.8 \mathrm{E}+05$ & 0.48 \\
\hline $\mathrm{C} 2$ & 7.7 & 0.014 & 0.026 & 0.040 & 0.081 & 0.126 & 0.207 & 0.095 & 0.152 & 0.247 & $16 \%$ & 10519 & 16364 & 26883 & $7.5 \mathrm{E}+05$ & 0.75 & $6.3 \mathrm{E}+05$ & 0.63 \\
\hline $\mathrm{C} 3$ & 6.1 & 0.011 & 0.025 & 0.036 & 0.053 & 0.086 & 0.139 & 0.064 & 0.111 & 0.175 & $21 \%$ & 8689 & 14098 & 22787 & $7.9 \mathrm{E}+05$ & 0.79 & $5.6 \mathrm{E}+05$ & 0.56 \\
\hline $\mathrm{C} 4$ & 6.1 & 013 & 0.027 & 0.040 & 0.031 & 0.052 & 0.083 & 0.044 & 0.079 & 0.123 & $33 \%$ & 5082 & 8525 & 13607 & $3.9 \mathrm{E}+05$ & 0.39 & $3.2 \mathrm{E}+05$ & 0.32 \\
\hline $\mathrm{C} 5$ & 3.2 & 0.007 & 0.010 & 0.017 & 0.006 & 0.008 & 0.014 & 0.013 & 0.018 & 0.031 & $55 \%$ & 1875 & 2500 & 4375 & $2.7 \mathrm{E}+05$ & 0.27 & $2.5 \mathrm{E}+05$ & 0.25 \\
\hline C6 & 3.4 & 0.008 & 0.014 & 0.022 & 0.014 & 0.024 & 0.038 & 0.022 & 0.038 & 0.060 & $37 \%$ & 4118 & 7059 & 11176 & $5.1 \mathrm{E}+05$ & 0.51 & $5.0 \mathrm{E}+05$ & 0.50 \\
\hline C7 & 0.3 & 0.005 & 0.005 & 0.010 & 0.002 & 0.001 & 0.003 & 0.007 & 0.006 & 0.013 & $77 \%$ & & & & $1.3 \mathrm{E}+06$ & 1.33 & $6.7 \mathrm{E}+05$ & 0.67 \\
\hline $\mathrm{C} 8$ & 1.9 & 0.011 & 0.019 & 0.030 & 0.030 & 0.051 & 0.081 & 0.041 & 0.070 & 0.111 & $27 \%$ & 15789 & 26842 & 42632 & $1.4 \mathrm{E}+06$ & 1.44 & $1.4 \mathrm{E}+06$ & 1.41 \\
\hline C9 & 7.7 & 0.004 & 0.006 & 0.010 & 0.076 & 0.126 & 0.202 & 0.076 & 0.126 & 0.202 & $5 \%$ & 9870 & 16364 & 26234 & $2.5 \mathrm{E}+06$ & 2.47 & $2.7 \mathrm{E}+06$ & 2.73 \\
\hline $\mathrm{C} 10$ & 4.3 & 011 & 0.022 & 0.033 & 0.092 & 0.149 & 0.241 & 0.103 & 0.171 & 0.274 & $12 \%$ & 21395 & 34651 & 56047 & $1.9 \mathrm{E}+06$ & 1.95 & $1.6 \mathrm{E}+06$ & 1.58 \\
\hline $\mathrm{C} 11$ & 3.0 & 0.007 & 0.013 & 0.020 & 0.012 & 0.021 & 0.033 & 0.019 & 0.034 & 0.053 & $38 \%$ & 4000 & 7000 & 11000 & $5.7 \mathrm{E}+05$ & 0.57 & $5.4 \mathrm{E}+05$ & 0.54 \\
\hline $\mathrm{C} 12$ & 0.5 & 0.043 & 0.083 & 0.128 & 0.008 & 0.013 & 0.019 & 0.051 & 0.096 & 0.147 & $87 \%$ & 16000 & 26000 & 42000 & $3.7 \mathrm{E}+05$ & 0.37 & $3.1 \mathrm{E}+05$ & 0.31 \\
\hline $\mathrm{C} 13$ & 5.1 & 0.011 & 0.025 & 0.036 & 0.042 & 0.071 & 0.113 & 0.053 & 0.096 & 0.149 & $24 \%$ & 8235 & 13922 & 22157 & $7.5 \mathrm{E}+05$ & 0.75 & $5.6 \mathrm{E}+05$ & 0.56 \\
\hline $\mathrm{C} 14$ & 10.4 & 0.005 & 0.009 & 0.014 & 0.007 & 0.011 & 0.018 & 0.012 & 0.020 & 0.032 & $44 \%$ & 673 & 1058 & 1731 & $1.3 \mathrm{E}+05$ & 0.13 & $1.2 \mathrm{E}+05$ & 0.12 \\
\hline $\mathrm{C} 15$ & 2.0 & 0.009 & 0.016 & 0.025 & 0.005 & 0.013 & 0.018 & 0.014 & 0.029 & 0.043 & $58 \%$ & 2500 & 6500 & 9000 & $2.8 \mathrm{E}+05$ & 0.28 & $4.1 \mathrm{E}+05$ & 0.41 \\
\hline & & & & & & & & & & & & & & Median & $5.7 \mathrm{E}+05$ & 0.57 & $5.4 \mathrm{E}+05$ & 0.54 \\
\hline
\end{tabular}

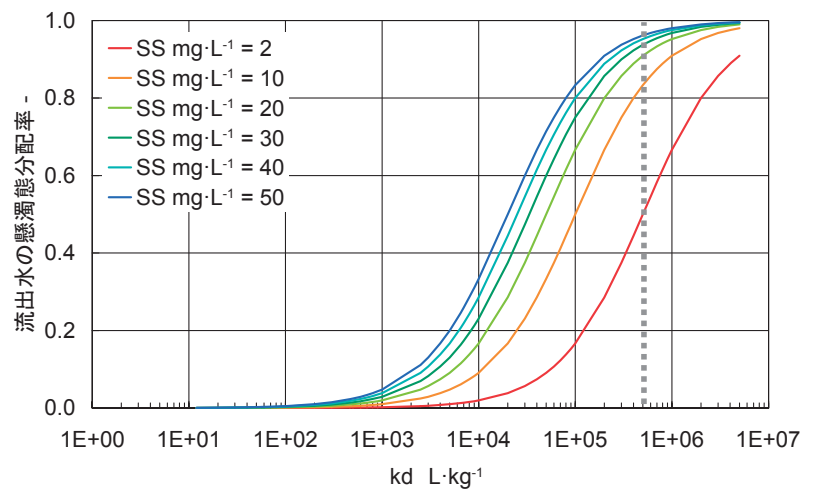

図2 流出水に打ける懸濁物質 (SS) 濃度毎の懸濁物質・水 分配係数 $\mathrm{kd}$ と懸濁態分配率の関係 (図中の点線は本研 究に抢ける懸濁物質・水分配係数 $\mathrm{kd}$ の設定值)

要素, 河川流量, 䀣濁物質および放射性セシウムは図 1 に示す地点において観測が実施されている。

\section{1 解析条件の設定}

3 次メッシュ（約 $1 \mathrm{~km}$ 格子）を基礎単位として阿武 隈川水系をモデル化した結果，全部で 5279 メッシュと なった。流域の土地利用は山林が約 $79 \%$, 田や畑等の 農地が約 $18 \%$, 宅地等の市街地が約 3\%となっており, 流域の大部分が山林で占められている。

表 1 は解析目的別の対象期間を示したものである。 放射性セシウムの河川水濃度の数值シミュレーション は, 原発事故前の 2010 年 12 月 1 日から 2012 年 12 月 31 日までとし，この期間に解析モデルの全てを検証し た。ただし，熱収支解析と流れ解析は，2008 年 12 月 1 日から 2009 年 12 月 31 日までの期間を対象に予め決定 できないモデル定数のキャリブレーションを実施した。 気象要素は, 若松, 仙台, 福島, 白河, 小名浜の 5 つの 気象官署を利用した。熱収支解析では, 気象官署の福島, 白河における積雪深の推定值が観測值 ${ }^{17)}$ に整合するよう に, バルク係数, 蒸発効率, アルベド, 人工排熱量をキャ リブレーションにより決定した。流れ解析では, 阿武隈 川水系の観測地点における流量の推定值が観測值 ${ }^{18)}$ に整 合するように, 土地利用別の表面流出係数, $\mathrm{A} \sim \mathrm{D}$ 層
の土壤空隙率, $\mathrm{A}$ 層の透水係数と $\mathrm{B} \sim \mathrm{D}$ 層の水平流出 係数および鉛直流出係数をキャリブレーションにより決 定した。

\subsection{1 懸濁物質・水分配係数 $\mathrm{kd}$ の設定}

放射性セシウムに関しては，細粒な土壤粒子に吸着さ れやすいこと ${ }^{19)}, \mathrm{pH}$ や有機物濃度などの環境要因によっ て, 溶存態, 交換態, 懸濁態と存在形態が異なること ${ }^{20)}$, 各土地利用や各土壤における吸着性等のパラメー夕の 評価は今後の課題であること ${ }^{21)}$ が指摘されている。今の ところ, 放射性セシウムの流出水に打䀣濁物質・水 分配係数 $k d$ について, 環境条件に依存したパラメー夕 の設定を可能にする知見が十分に蓄積されていないこ とから，ここでは，阿武隈川水系に打ける放射性セシ ウムの存在形態別濃度の観測值に基づいて $k d$ を設定し た。Yasutaka et al. ${ }^{22}$ )が阿武隈川水系内の全 15 地点 (図 1: $\mathrm{C} 1 \sim \mathrm{C} 15$ 地点）で測定した放射性セシウムの溶存態濃 度, 懸濁物質濃度およびそれに含まれる懸濁態濃度に基 づいて各地点の $k d$ を算出した結果, セシウム 134 は 1.3 $\times 10^{5} \sim 2.5 \times 10^{6}\left(\mathrm{~L} \cdot \mathrm{kg}^{-1}\right)$, セシウム 137 は $1.2 \times 10^{5}$ 〜 $2.7 \times 10^{6}\left(\mathrm{~L}^{\circ} \mathrm{kg}^{-1}\right)$ の範囲に収まっており，それぞれ の中央值である $5 \times 10^{5}\left(\mathrm{~L} \cdot \mathrm{kg}^{-1}\right)$ に設定した (表 2 参照)。 図 2 は Eq.4 に基づき, 懸濁物質濃度毎の流出水の懸濁 態分配率を示したものである。懸濁物質濃度が $10(\mathrm{mg}$. $\left.\mathrm{L}^{-1}\right)$ では賏濁態分配率が約 $80 \%$, 㲘濁物質濃度が $2(\mathrm{mg}$. $\left.\mathrm{L}^{-1}\right)$ では溶存態と䀣濁態の分配率が同程度となった。 これより, $k d$ だけでなく流出水の賏濁物質濃度に応じ て䁻濁態分配率が変化することから, 流域における㲘濁 物質の流出ポテンシャルがそのまま放射性セシウムの存 在形態を決定する重要な要因であると考えられる。

\subsection{2 流域における懸濁物質の流出負荷量の設定}

流域土壤から河川への放射性セシウムの流出は, 主に 眯濁物質の移動に伴うことが報告されていることから ${ }^{11)}$, 放射性セシウムの動態を考慮するには眯濁物質の流出ポ テンシャルを評価することが重要となる。例えば, 山林 では降水による出水に伴う流域土壤の表面侵食が放射性 物質を移動させる駆動力となり, 出水時の䀣濁物質と放 
射性セシウム濃度には高い相関があることが示されてい る ${ }^{11,23)}$ 。前述のように阿武隈川流域の土地利用はその大 部分が山林であることから，ここでは，土地利用別に䁻 濁物質の流出ポテンシャルは評価せずに，阿武隈川の伏 黒地点（図 1：Q7 地点）と阿久津地点（図 1：Q12 地 点）における流量と懸濁物質の毎月の観測結果 ${ }^{24)}$ を利 用して，次に示す LQ 式により流出負荷量を設定した (図 3 参照)。

$$
L=\alpha Q^{\beta}, \alpha=925.626, \beta=2.325 \ldots \ldots \ldots \cdots \cdots \cdots \cdots \cdots
$$

ここに, $L$ : 比負荷量 $\left(\mathrm{g} \cdot \mathrm{s}^{-1} \cdot \mathrm{km}^{-2}\right), Q$ : 比流量 $\left(\mathrm{m}^{3} \cdot \mathrm{s}^{-1} \cdot \mathrm{km}^{-2}\right)$ である。

比流量には河川への横流入量となる $\mathrm{A} \sim \mathrm{C}$ 層の斜面 流出量を設定し, $\mathrm{LQ}$ 式の係数である $\alpha$ と $\beta$ の妥当性は河 川水の懸濁物質濃度をもって検証した。

3.1 .3 放射性セシウムに関する解析条件の設定

(1)流域における蓄積量の設定

本研究では, 放射性セシウムの蓄積量の初期条件やそ の後の蓄積量の実態として, 文部科学省放射線量等分 布マップ拡大サイト ${ }^{12)}$ の航空機モニタリング結果の沈着 量を利用した。表 3 に示すように, この結果は沈着量 の下限值が調查時点毎に異なっており注意が必要であ る。放射性セシウムの排出源は大気から地上に降下した

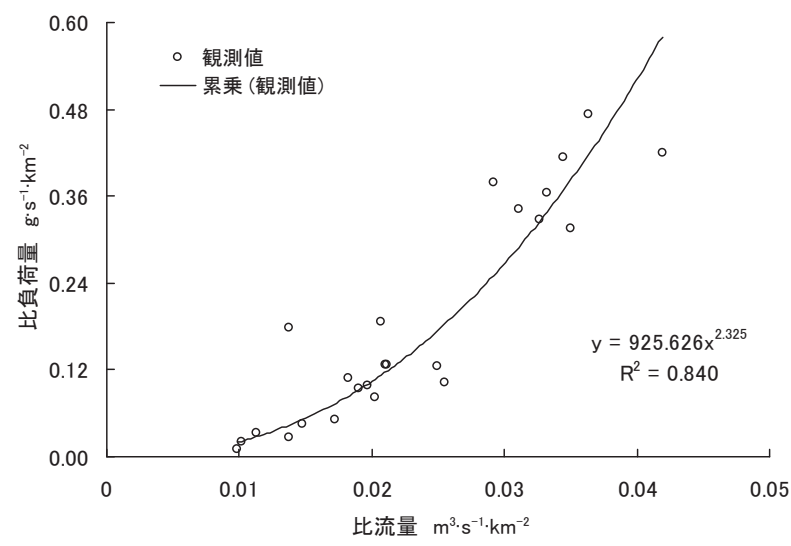

図3 比流量と懸濁物質 (SS) の比負荷量の関係
沈着量のみと仮定し，蓄積量の初期条件に第 1 次調査の 2011 年 4 月 29 日の沈着量を設定した。ただし, 第 1 次 調査と第 2 次調査の下限值は第 3 次調査以降のそれと異 なるため, ここでは第 1 次調査の沈着量が $300\left(\mathrm{kBq} \cdot \mathrm{m}^{-2}\right)$ のとき, 下限值が $10\left(\mathrm{kBq} \cdot \mathrm{m}^{-2}\right)$ である調査のうち, 調 査時点が最も第 1 次調査に近い第 3 次調査の值に置き換 えた。

\section{(2)物性の設定}

前述の通り，放射性セシウムの懸濁物質 - 水分配係数 $k d$ は $5 \times 10^{5}\left(\mathrm{~L}^{\mathrm{kg}} \mathrm{kg}^{-1}\right)$, 半減期はセシウム 134 を 2.1 年, セシウム 137 を 30 年に設定した。また, 放射性セシウ 厶の堆積負荷掃流モデルにある負荷流出係数 $k f\left(\mathrm{~m}^{-2}\right)$ は, Eq.5 を時間積分して得られる次式により設定した。

$$
k f=\ln \left(\frac{S(t)}{S(0) \cdot \exp (-k r \cdot t)}\right) \frac{1}{f s \cdot q \cdot t} \quad \cdots \cdots \cdots \cdot \operatorname{Ep} .16
$$

ここに, $t$ : 対象期間の延べ時間 $(\mathrm{s}), S(0)$ : 第 1 次調 査における蓄積量（沈着量） $\left(\mathrm{Bq} \cdot \mathrm{m}^{-2}\right), S(t)$ : 対象期間 経過後の蓄積量 $\left(\mathrm{Bq} \cdot \mathrm{m}^{-2}\right)$ である。

Eq.16における $f s$ を 1 (䀣濁物質濃度が十分に高い), 降水の流出係数を流域平均で 0.2 と仮定したうえで，期 間内の延べ時間数, 流出量, 土壤における蓄積量の残存 率および消失速度を考慮した結果, 出水に伴う負荷量の 流出割合を示す負荷流出係数 $k f$ は表 4 に示す結果を得 た。これより，セシウム 134 およびセシウム 137 ともに 負荷流出係数 $k f$ は $5 \times 10^{-5}\left(\mathrm{~m}^{-2}\right)$ に設定した。土壌に おける蓄積量の残存率 $S(t) / S(0)$ は, 図 4 に示すように 第 1 次調查の沈着量に対する第 5 次調査の沈着量の割合 を設定した。

表3 文部科学省 ${ }^{12)}$ による沈着量の公表值に関する下限値の一覧

\begin{tabular}{|c|c|c|}
\hline \multicolumn{2}{|c|}{ 調査時点 } & $\begin{array}{c}\text { 沈着量の下限値 } \\
\mathrm{kBq} \cdot \mathrm{m}^{-2}\end{array}$ \\
\hline 第1次 & 2011年4月29日 & 300 \\
\hline 第2次 & 2011年5月26日 & 100 \\
\hline 第3次 & 2011年7月2日 & 10 \\
\hline 第4次 & 2011年11月5日 & 10 \\
\hline 第5次 & 2012年6月28日 & 10 \\
\hline
\end{tabular}

\begin{tabular}{|c|c|c|c|}
\hline 対象物質 & $\begin{array}{c}\mathrm{S}(\mathrm{t}) / \mathrm{S}(0) \\
-\end{array}$ & $\begin{array}{c}\text { 消失速度 } k r \\
s^{-1}\end{array}$ & $\begin{array}{c}\text { 負荷流出係数 } \mathrm{kf} \\
\mathrm{m}^{-2}\end{array}$ \\
\hline セシウム134 & 0.498 & $1.047 \mathrm{E}-08$ & $4.264 \mathrm{E}-05$ \\
\hline セシウム137 & 0.676 & $7.327 \mathrm{E}-10$ & $4.984 \mathrm{E}-05$ \\
\hline
\end{tabular}

表 4 負荷流出係数の設定結果

1) 期間内の延べ時間 day: 第1次(2011/4/29)〜第5次(2012/6/28)の前日まで

2) 期間内の降水量 $\mathrm{mm}$

$1.626 \mathrm{E}+03$

3) 期間内の流出量 $\mathrm{m}^{3}$ $1.691 \mathrm{E}+09$

4) 期間内の流出量(流路長あたり) $\mathrm{m}^{2}$

$7.315 \mathrm{E}+03$

5) 流域面積 $\mathrm{km}^{2}$

$5.279 \mathrm{E}+03$

6) 流路長 $\mathrm{km}$ : 流路長 $=1.35 \times$ 流域面積 ${ }^{0.6}$ (文献25)）

$2.311 \mathrm{E}+02$

7) 流出係数 -

\begin{tabular}{|c|r|r|}
\hline 土地利用 & 面積率 - & 流出係数 - \\
\hline 山林 & 0.79 & 0.20 \\
\hline 田畑 & 0.18 & 0.10 \\
\hline 市街地 & 0.03 & 0.70 \\
\hline 流域平均 & 1.00 & 0.20 \\
\hline
\end{tabular}




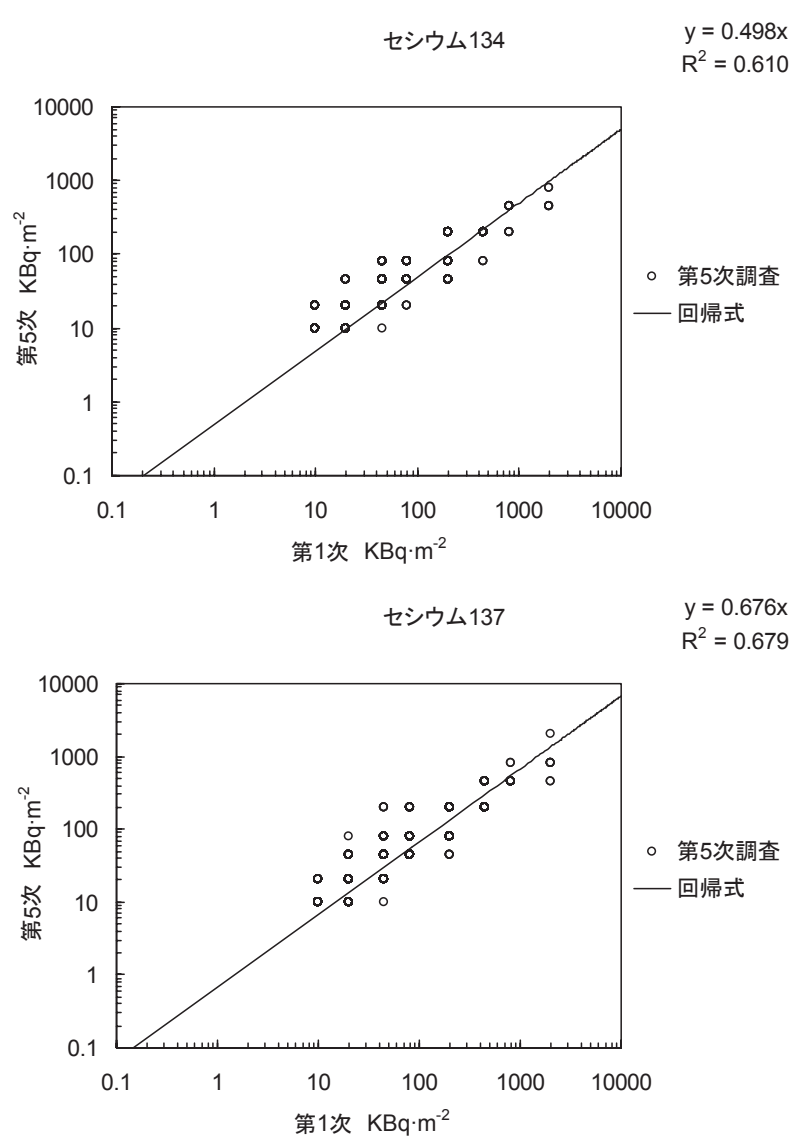

図4 第 1 次調查地点と第 5 次調查地点に打ける放射性物質 の蓄積量の比較

\section{2 本モデルの検証に用いる観測值}

本モデルの検証には, 2011 年から 2012 年までの $\mathrm{JAEA}^{6)}$ (図 $1: \mathrm{J} 1 \sim \mathrm{J} 23$ 地点), 環境省 ${ }^{8)}$ (図 1: K1 〜 K5 地点), Yasutaka et al. ${ }^{22)}$ (図 1: C1 C15 地点) による 観測值を用いた。JAEA は2011年の 6/29〜 7/1, 8/1〜 8/2, 12/21 12/22 の全部で 3 回の河川水の放射性セシ ウム濃度の観測值を公開している。環境省は東日本大震 災の被災地を中心とした福島県, 宮城県, 岩手県, 山形 県, 茨城県, 栃木県, 群馬県, 千葉県, 埼玉県および東 京都で, 1 年に数回の河川水の放射性物質濃度の調査を 実施している。Yasutaka et al. ${ }^{22)}$ は2012年の9/14〜9/15に, 阿武隈川水系の本川 7 箇所と支川 8 箇所において放射性 セシウムの溶存態, 懸濁態濃度および懸濁物質の濃度を 測定している。なお, 環境省の測定結果の殆どは不検出 となる $1\left(\mathrm{~Bq} \cdot \mathrm{L}^{-1}\right)$ 未満と記載されているため, 検出濃 度のみを抽出した。

\section{3 モデルの検証}

ここでは，本モデルにある熱収支解析，流れ解析，水 質解析, 物質動態解析の 4 つのサブモデルの妥当性を検 証した。

(1)熱収支解析モデルの検証

阿武隈川水系では冬季から春季にかけての積雪融雪が 特徵であり，この現象を熱収支解析モデルにより再現し た。図 5 は気象官署の福島地方気象台と白河特別地域 気象観測所における積雪深の推定值と観測值とを比較し たものであり，何れの地点でも両者の傾向は概ね一致し ており，本モデルは概ね妥当であると判断した。

福島

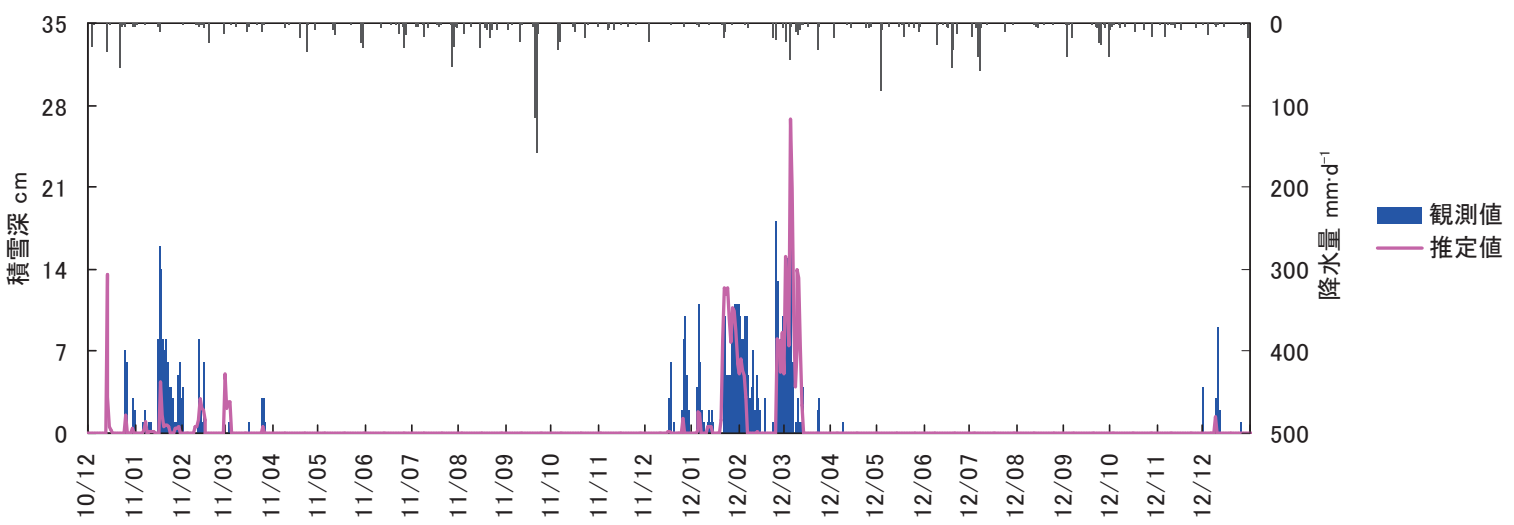

白河

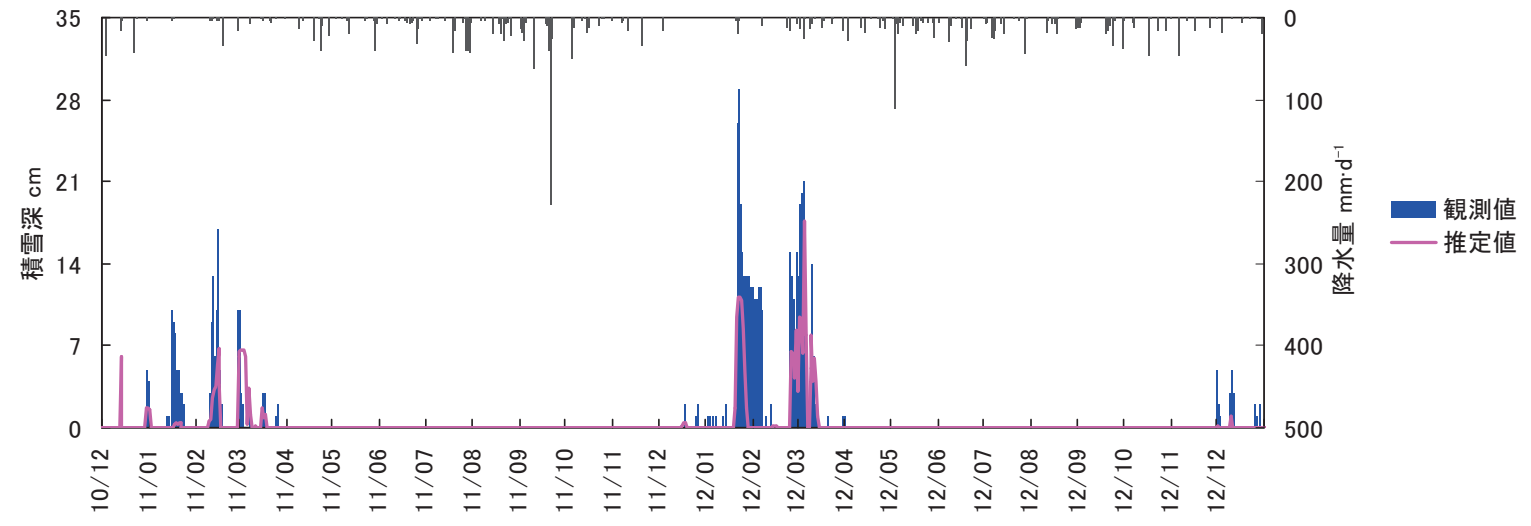

図5 積雪深の経時変化に係る推定值と観測值の比較 

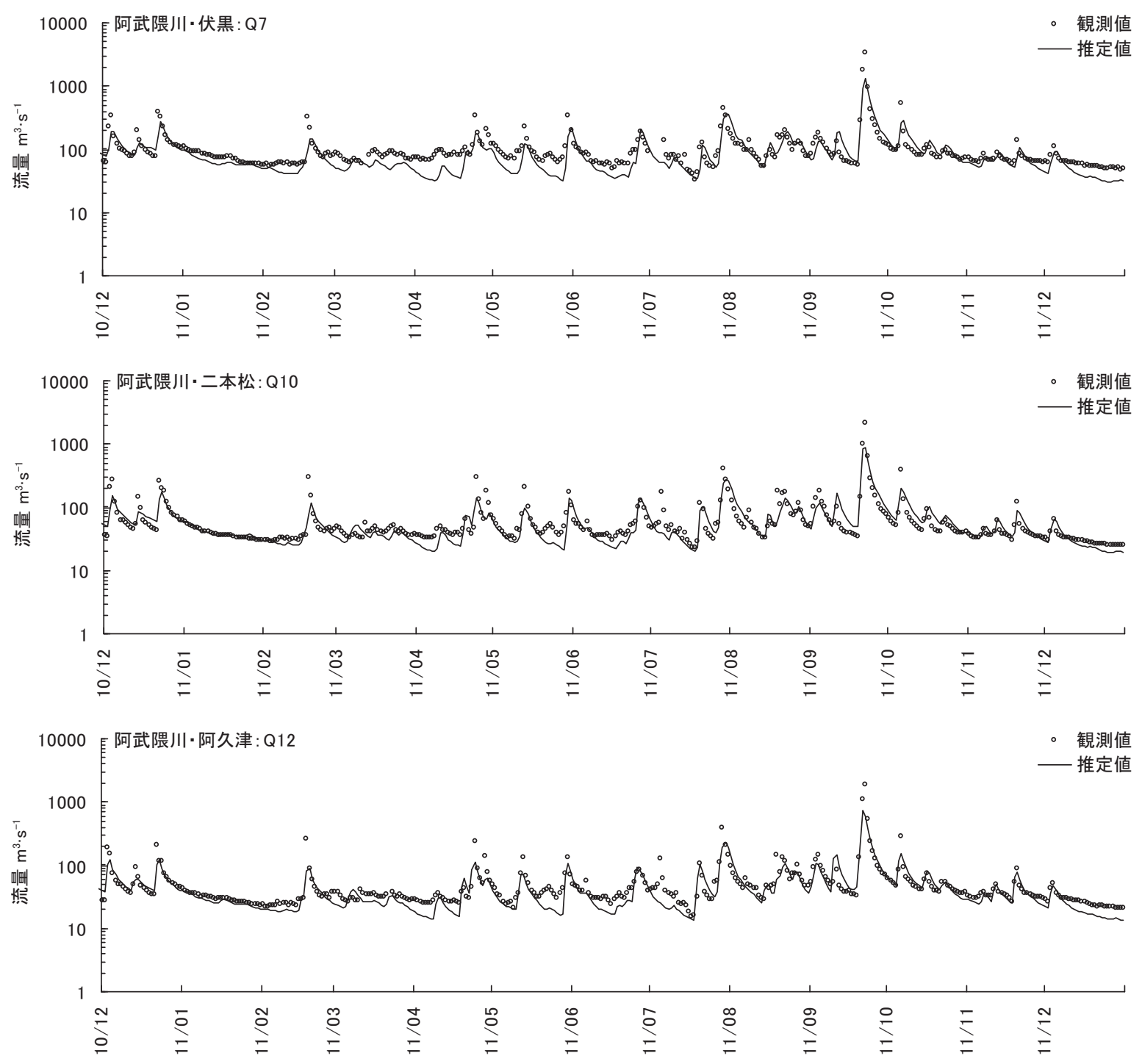

図6 河川流量の経時変化に係る推定值と観測值の比較

\section{(2)流れ解析モデルの検証}

図 6 は阿武隈川における流量の基準観測地点である 伏黒地点 (図 1:Q7 地点), 二本松地点 (図 1:Q10 地点), 阿久津地点（図 1：Q12 地点）を対象に, 流れ解析モデ ルによる河川流量の推定值と観測值を比較したものであ る。この結果, 両者は流量の大きさだけでなく経時的な 変化傾向も一致していることが確認できた。さらに，河 川流量の推定精度を定量評価した。評価指標は藤原によ る研究成果 ${ }^{26)}$ にある誤差評価関数を用いた。この研究は 河川流量を推定する流れ解析のモデル定数を最適化手法 により決定するための方法論と適用事例を示したもので ある。誤差評価関数には高水部の誤差を重視する RMSE （Root Mean Square Error）と低水部の誤差を重視する $R R$ (Root Mean Square of Relative Error) があり，何れの值も 小さいほど推定精度は良好とするものである。

$$
R M S E=\frac{1}{Q_{m}} \sqrt{\frac{1}{n} \sum_{i=1}^{n}\left(Q_{e s t}-Q_{o b s}\right)^{2}},
$$$$
Q_{m}=\frac{\sum_{i=1}^{n} Q_{o b s}}{n}
$$

$$
R R=\sqrt{\frac{1}{n} \sum_{i=1}^{n} \frac{\left(Q_{e s t}-Q_{o b s}\right)^{2}}{Q_{o b s}^{2}}}
$$

ここに, $Q_{o b s}$ : 河川流量の観測值, $Q_{e s t}$ : 河川流量の推定 值, $n:$ デー夕数である。

表 5 は誤差評価関数を用いて河川流量の推定精度を 定量評価したものである。この結果, RMSE は約 1 程度, $R R$ は約 0.5 以下にあり, 藤原による研究成果 $(R M S E$ は 約 0.85 以下, $R R$ は約 0.4 以下) ${ }^{26)}$ と比較してほぼ同じ精 度であった。これより, 河川流量は良好に推定されてい ることが示された。

(3)水質解析および放射性セシウムの動態解析モデルの 検証

図 7 は放射性セシウムの動態に影響を及ぼす懸濁物 質の推定值と平常時における観測值を比較したものであ る。懸濁物質の河川水濃度が観測されている地点（図 1: C1 〜 C15 地点で 2012 年の 9/14 9/15 に各地点 1 回の 観測）の 15 デー夕 ${ }^{22}$ と, 2011 年度に毎月の懸濁物質の 河川水濃度が観測されている阿武隈川の伏黒地点 (図 1: Q7 地点) および阿久津地点（図 1:Q12 地点）の 24 デー 夕 ${ }^{24)}$ の全部で 39 データに対して, 推定值は 21 データが Factor2, 26 データが Factor3 の範囲内にあった。全デー 
表 5 河川流量の推定精度

\begin{tabular}{|c|c|r|r|r|}
\hline \multicolumn{2}{|c|}{ 地点名 } & データ数 & RMSE - & \multicolumn{1}{c|}{ RR - } \\
\hline 伏黒 & Q7 & 389 & 1.06 & 0.31 \\
\hline 福島 & Q8 & 396 & 0.96 & 0.31 \\
\hline 二本松 & Q10 & 396 & 1.07 & 0.29 \\
\hline 本宮 & Q11 & 396 & 0.92 & 0.29 \\
\hline 阿久津 & Q12 & 395 & 1.23 & 0.28 \\
\hline 須川賀川 & Q13 & 396 & 0.85 & 0.51 \\
\hline 注)対象期間は2010/12/1-2012/12/31のうち観測值のある
\end{tabular}

注)対象期間は2010/12/1-2012/12/31のうち観測值のある

2010/12/1-2011/12/31まで

夕の $67 \%$ が Factor3 の範囲内にあることから懸濁物質の 河川水濃度は比較的良好に推定されているものと考えら れる。

図 8 は $\mathrm{JAEA}^{6)}$, 環境省 ${ }^{8)}$, Yasutaka et al. ${ }^{22)}$ の主に平常 時における観測による放射性セシウムの全濃度を対象に 推定值と観測值を比較したものである。推定值は観測值 より高くなる場合と低くなる場合の両方があり, 推定值 は過大にも過小にも評価されていないことが示された。 セシウム 134 は全デー夕 63 個のうち $75 \%$, セシウム 137 は全データ 67 個のうち $76 \%$ の推定值が Factor10, すなわち, 推定值は観測值に対して概ね 1 オーダーの範 囲内にあった。なお，この傾向に関して本川と支川で差 異は見られなかった。

図 9 および図 10 は放射性セシウムの河川水における 存在形態を検証するため, それぞれセシウム 134 とセシ ウム 137 毎に溶存態と䀣濁態の推定值と観測值を比較し たものである。この結果, 存在形態別の河川水濃度を観 測した Yasutaka et al. ${ }^{22)}$ の調査地点 (図 1:C1〜C15 地点) において，推定值は概ね Factor10，すなわち，推定值は 観測值に対して1オーダーの範囲内にあった。これより， 本モデルによる放射性セシウムの河川水濃度の推定はそ の大きさだけでなく, 溶存態や䀣濁態別の存在比率につ いても妥当な精度で推定していることが示された。

図 11 は阿武隈川における河川流量, 河川水の䀣濁物質 および放射性セシウムの各濃度の推定值の経時変化を示 したものである。放射性セシウムの濃度は, 䝮濁物質の 濃度に応じて高くなる傾向が示された。1 月前後の積雪 期では, 懸濁態濃度よりも溶存態濃度の方が高くなるこ とが多かった。これは出水により㲘濁物質と放射性物質 が流出した後, 出水が少ないことにより懸濁物質濃度が 低くなり，放射性物質が溶存態に再分配されたものと考 えられる。放射性セシウムの全濃度に占める懸濁態の割 合に関して, 阿武隈川の下流域にあたる伏黒地点（図 1： Q7 地点）では, セシウム 134, セシウム 137 によらず 2011 年では約 99\%，2012 年では約 95\%と推定され，河 川水濃度の殆どは懸濁態であることが示された。2011 年と 2012 年の $4 \%$ の違いは, 2011 年は原発事故が 3 月 に発生しており 1 2 月の積雪期を含んでいないものの, 2012 年は積雪期を含んでいることが考えられる。本モ デルは放射性物質を対象場の懸濁物質濃度に応じて逐 次, 溶存態と懸濁態に再分配して濃度を推定しているた め,このような現象を再現することができる。㲘濁物質・ 水分配係数 $k d$ を $5 \times 10^{-5}\left(\mathrm{~L} \cdot \mathrm{kg}^{-1}\right)$ とする条件下では, 図 2 に示すように懸濁物質濃度が $2\left(\mathrm{mg} \cdot \mathrm{L}^{-1}\right)$ を下回る とき，観測結果からも確認できるように放射性セシウム の濃度レベルに関して溶存態が䁻濁態を上回っており,

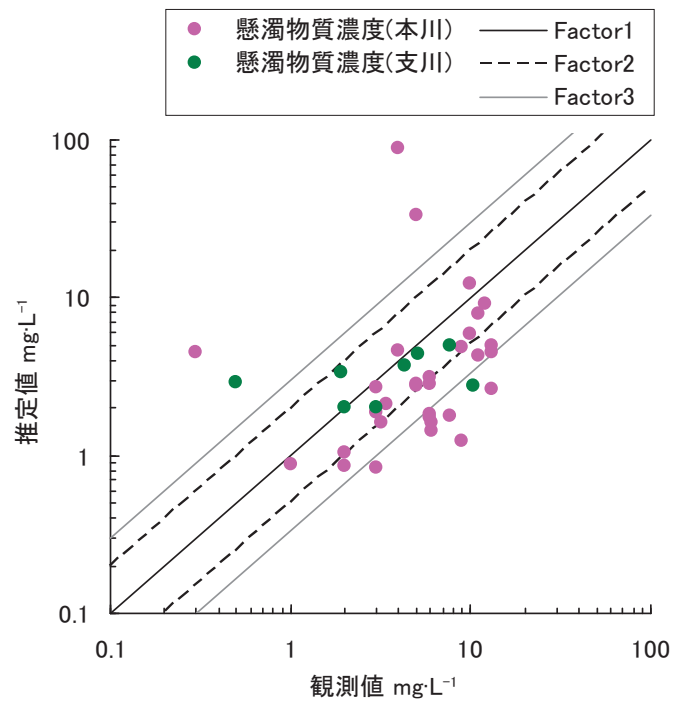

図7 河川水における圎濁物質濃度の推定值と観測值の比較

積雪期の状況に相当する。

表 6 は放射性セシウムの蓄積量を経過日数別に推定 した結果を示したものである。本モデルにおける風によ る飛散や除染を考慮しない条件下, 蓄積量は放射性物質 の自然崩壊による消失と降水に伴う出水による流域か らの流出でのみしか減少しないと考えられる。2011 年 4 月 29 日の第 1 次調査から 2012 年 12 月 31 日の間, セシ ウム 134 , セシウム 137 によらず降水に伴う流出による 消失は $1.6 \%$ とごく僅かであることは特筆すべきであり, 特に半減期の長いセシウム 137 は今後も流域に残存する ことが予想されることから, 蓄積量を減少させるのは困 難であると考えられる。

文部科学省の第 6 次航空機モニタリングの測定結果に よると, 第 4 次航空機モニタリングと第 6 次航空機モニ タリングの期間に福島第一原子力発電所から $80 \mathrm{~km}$ 圈内 における空間線量率が約 $40 \%$ 減少している傾向が報告 されている ${ }^{27)}$ 。この期間における放射性セシウムの物理 的減衰に伴う空間線量率の減少は約 $21 \%$ であることか ら, 空間線量率の減少傾向は, 放射性セシウムの物理的 減衰に伴う空間線量率の減少よりも大きいことが確認さ れた。この要因として, 放射性セシウムの物理的減衰以 外に, 降水等の自然環境の影響が挙げられる。例えば, 降水による表面流出に伴う河川経由の放射性セシウムの 域外への流出, 原発事故以降の針葉樹の落葉による見か け上の森林上層の空間線量の低下, 森林 - 農地等の土壤 中への浸透に伴う遮蔽効果による空間線量の低減, 除染 の効果などが考えられる。本研究の結果からは降水によ る流出に伴う消失は前述の通り $1.6 \%$ と推定されており, 今後は降水以外による空間線量率の減少要因を解明する 必要があると考える。

4. おわりに

2011 年 3 月の福島第一原発事故により放出された放 射性物質の河川流域での挙動を解析するには, 放射性物 質の流域土壤への沈着, 降水による出水に伴う流域土壤 から河川への放射性物質の移動を時間的, 空間的に把握 することが必要である。現在までに, 河川等の水域にお いて放射性物質の観測が実施されているものの, 主に観 

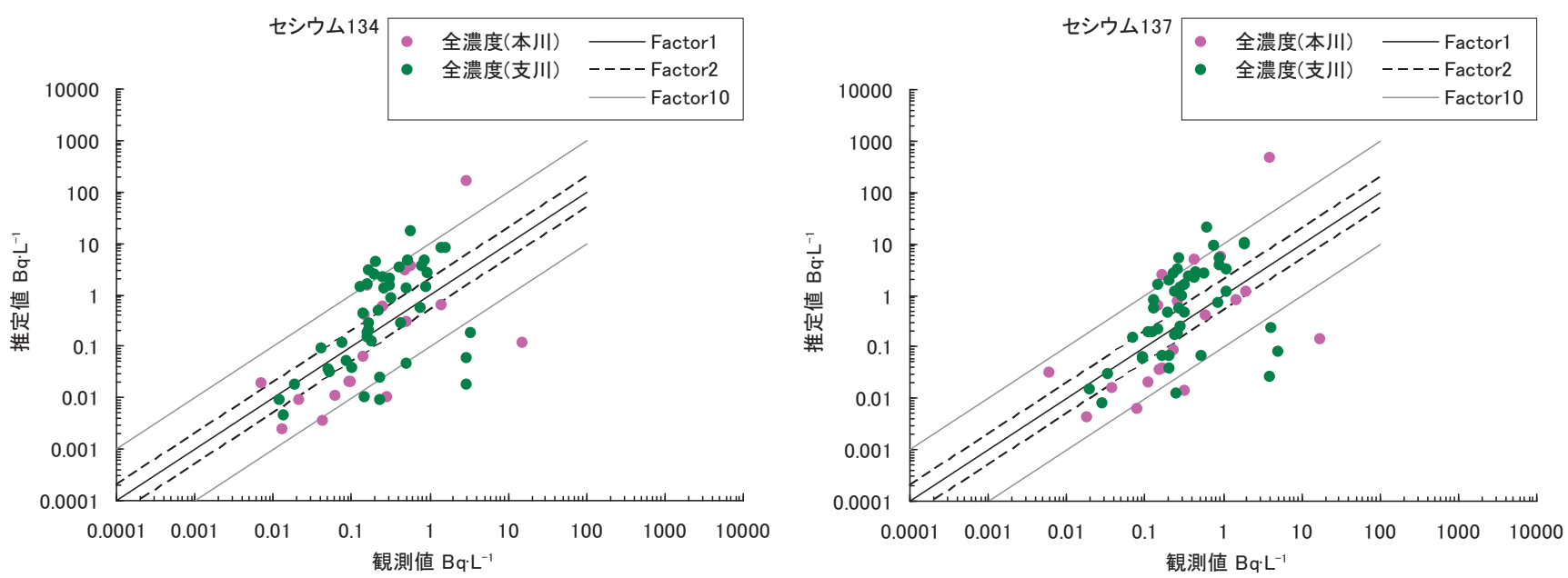

図8＼cjkstart河川水における放射性セシウム全濃度の推定值と観測值の比較
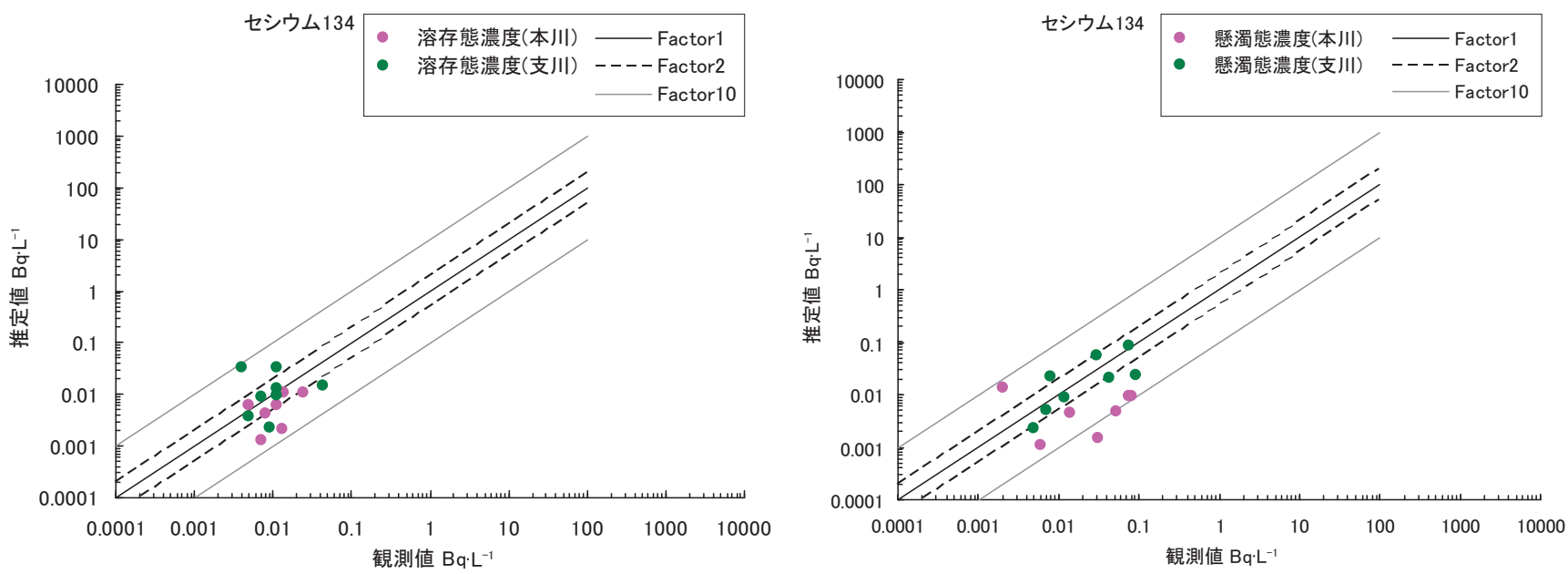

図 9 河川水に打ける放射性セシウムの存在形態別濃度の推定值と観測值の比較 (セシウム 134)
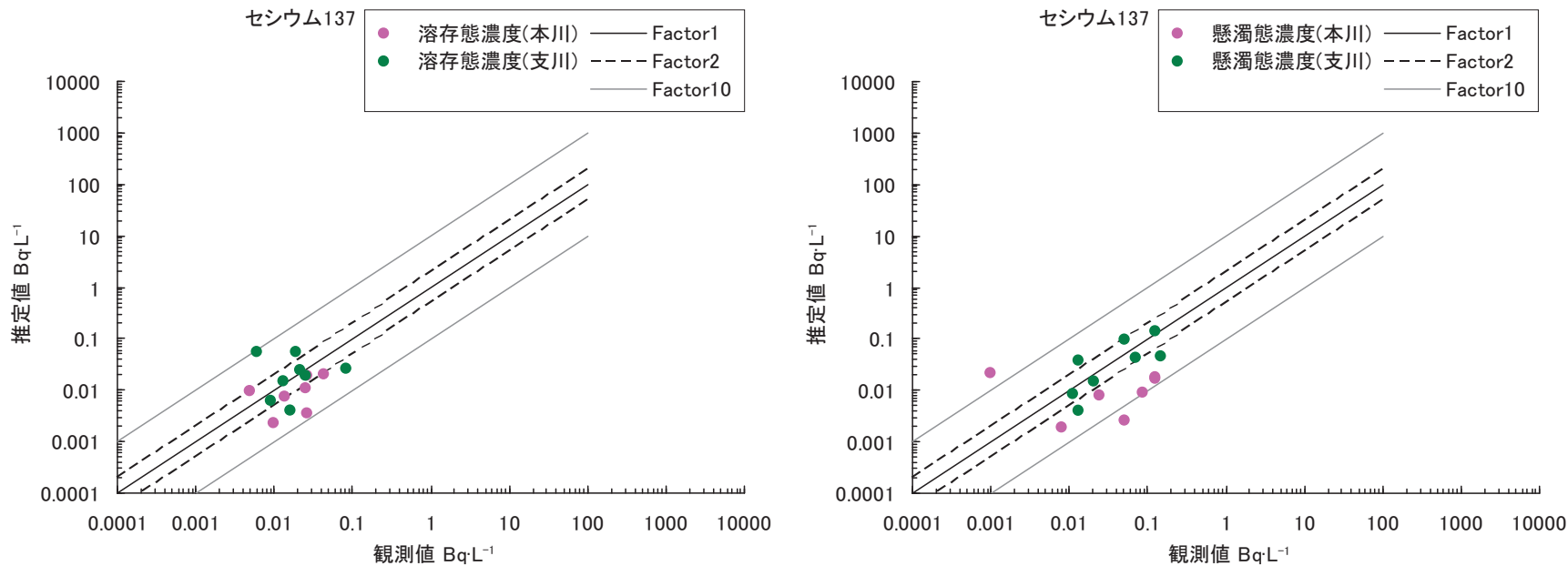

図 10 河川水における放射性セシウムの存在形態別濃度の推定值と観測值の比較 (セシウム 137) 

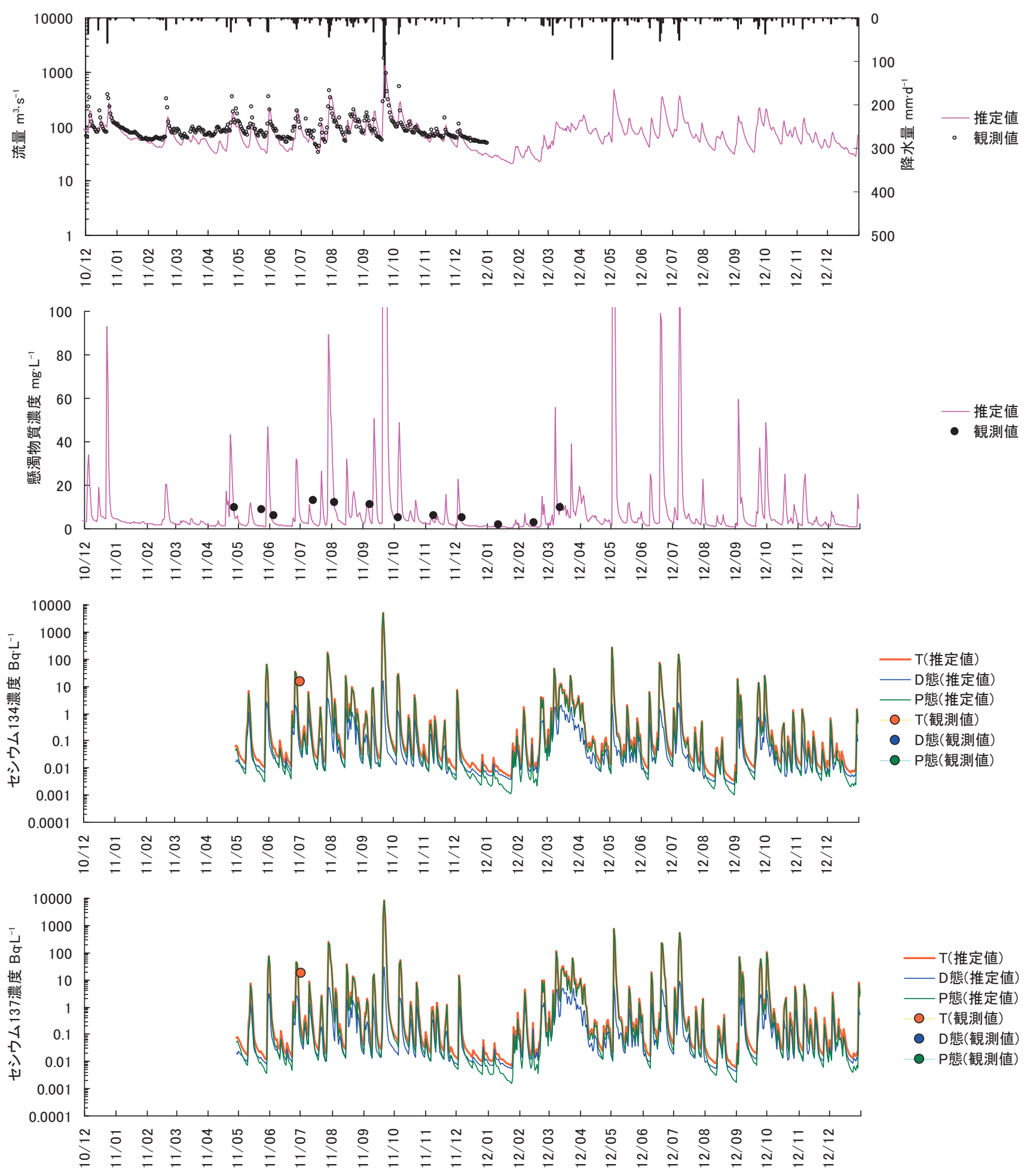

図11（1） 河川流量ならびに河川水における懸濁物質濃度と放射性セシウム濃度の経時変化

(阿武隈川下流域：伏黒地点 (Q7 地点), K1 地点) 

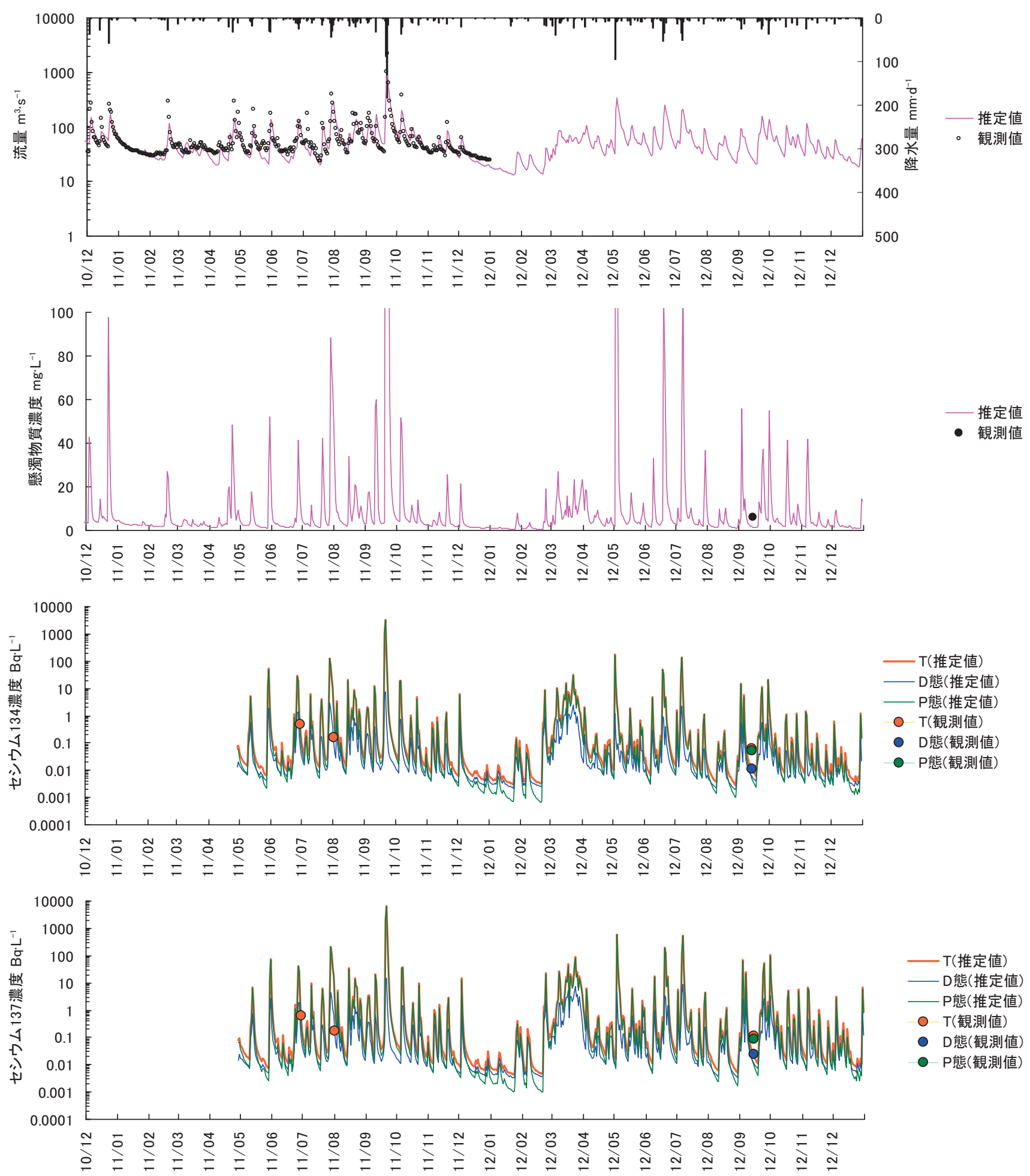

図11（2）河川流量ならびに河川水に扔ける懸濁物質濃度と放射性セシウム濃度の経時変化

(阿武隈川中流域：二本松地点 (Q10地点), C3 (J9) 地点) 

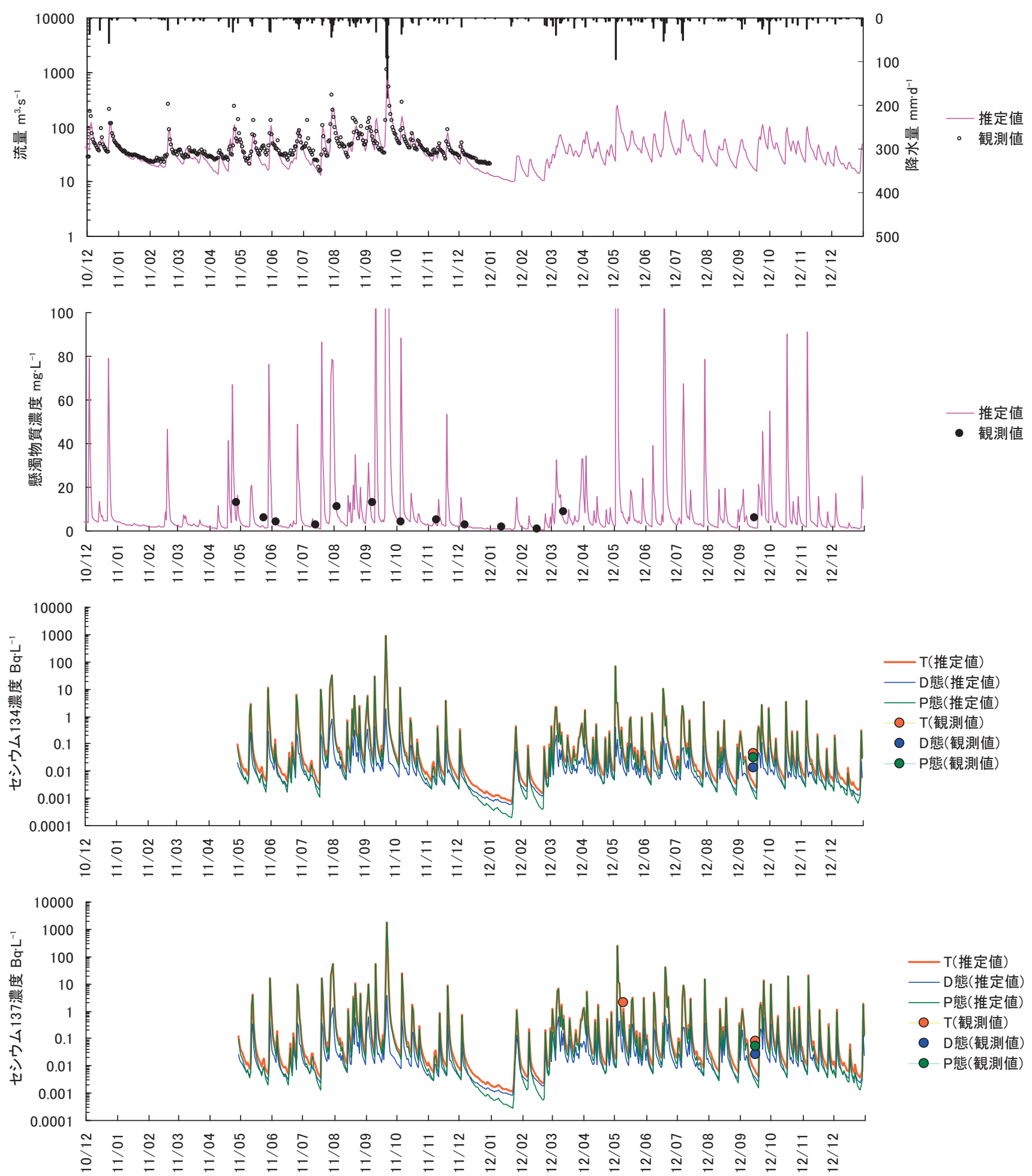

図 11 （3）河川流量ならびに河川水における懸濁物質濃度と放射性セシウム濃度の経時変化 (阿武隈川上流域：阿久津地点 (Q12地点), C4 (K4) 地点) 
対象水系全域における蓄積量の減少率の推定結果

\begin{tabular}{|c|c|c|c|c|c|c|c|c|c|}
\hline & \multirow{2}{*}{\multicolumn{3}{|c|}{ 期間 }} & \multicolumn{6}{|c|}{ 減少率 - } \\
\hline & & & & \multicolumn{3}{|c|}{ セシウム134 } & \multicolumn{3}{|c|}{ セシウム137 } \\
\hline 第1次～第4次 & $2011 / 04 / 29$ & $2011 / 11 / 04$ & 190 & 0.164 & 0.157 & 0.007 & 0.019 & 0.012 & 0.007 \\
\hline 第1次～2012/12/31 & $2011 / 04 / 29$ & $2012 / 12 / 31$ & 613 & 0.435 & 0.419 & 0.016 & 0.054 & 0.038 & 0.016 \\
\hline
\end{tabular}

測に要する時間間隔や観測密度の制約から高濃度となる 時期や地点を網羅的に把握することができない。本研究 では，放射性物質のうち放射性セシウムに着目し，その 動態を考慮して流域における蓄積量と河川水濃度の推定 を目的にモデル構築を図った。産総研 - 水系暴露解析モ デル（AIST-SHANEL）をプラットフォームとし，流域 における懸濁物質の流出ポテンシャルと放射性物質の動 態を考慮したモデルを導入し，阿武隈川水系を対象に本 モデルによるケーススタディーを実施した。その結果, 本モデルは流域における放射性物質の河川水濃度の時間 的・空間的変動を妥当に評価できることを示した。出水 時における放射性セシウムの河川水濃度のデータが得ら れなかったため, 平常時を対象とした本モデルの妥当性 を評価した。出水時における本モデルの妥当性は, 観測 データが蓄積された段階で実施する予定である。現時点 で，䀣濁物質に吸着しやすい放射性セシウムが降水によ る出水に伴って高濃度に至ること, 河川水など環境媒体 中の懸濁物質の濃度によっては懸濁態と溶存態の存在比 率が異なる場合があることを示した。具体的には，放射 性セシウムの全濃度に占める懸濁態の割合に関して, 阿 武隈川では, セシウム 134, セシウム 137 によらず 1 〜 2 月の積雪期を含まない 2011 年では約 $99 \%$, 積雪期を 含む 2012 年では約 $95 \%$ と推定され, 河川水濃度の殆ど は眯濁態であることを示す結果を得た。また，放射性セ シウムの流域における蓄積量の残存状況から，降水によ る出水に伴う流域土壌からの流出は阿武隈川水系全体で 僅かであることを示した。2011 年 4 月 29 日の第 1 次調 査から 2012 年 12 月 31 日の間, セシウム 134 , セシウ ム 137 によらず降水に伴う流出による消失は $1.6 \%$ とご く僅かであり, 特に, 半減期の長いセシウム 137 は自然 崩壊が少ないことも相まって流域での蓄積量が自然に減 少するには時間が必要であると考えられ，除染をはじめ 総合的な対策を検討することの必要性が示唆された。本 モデルは放射性セシウムの河川流域での挙動解析や污染 対策の評価を可能にするものと考えられる。

（原稿受付 2013 年 8 月 26 日) （原稿受理 2013 年 12 月 6 日）

\section{参 考 文 献}

1 ）石川奈緒, 内田滋夫,田上恵子 (2007) 放射性セシウムの水田土 壤への収着挙動における粘土鉱物の影響, RADIOISOTOPES, 56 , 519-528.

2 ) Nakao, A., Thiry, Y., Funakawa, S. and Kosaki, T. (2008) Characterization of the frayed edge site of micaceous minerals in soil clays influenced by different pedogenetic condition in Japan and northern Thailand, Soil Science and Plant Nutrition, 54, 479-489.

3 ) Takeda, A., Tsukada, H., Takaku, Y., Akata, N. and Hisamatsu, S. (2008) Plant induced changes in concentrations of caesium, strontium and uranium in soil solution with reference to major ions and dissolved organic matter, Journal of Environmental Radioactivity, 99, 900-911.

4 ）保高徹生, 中村公人, 三浦俊彦, 佐藤利夫, 黒沢亘, 掘田朝丈,
川辺能成, 張 銘 (2012) 複数種の土壤における放射性セシウムの 媣度分布と存在形態の比較, 第 47 回地盤工学会研究発表会講演 要旨, ROMBUNNO. 987.

5 ）保高徹生, 川本徹, 駒井武 (2013) 放射性セシウム含有土畩へ の酸抽出方法の適用性に関する基礎的検討, RADIOISOTPES, 62 , 211-218.

6 ）日本原子力研究開発機構 (2013) 平成 23 年度放射能測定調查 委託事業「福島第一原子力発電所事故に伴う放射性物質の第二 次分布状況等に関する調查研究」成果報告書 (第 2 編) 放射線 量等分布マップ関連調查研究, http://www.jaea.go.jp/fukushima/ kankyoanzen/mapping_report/2nd-japanese/2ndlist.html (平成 25 年 10 月時点).

7 ）環境省環境回復検討会 (2012) 今後の森林除染の在り方に関す る当面の整理について, http://www.env.go.jp/press/press.php?serial $=15731$ (平成 25 年 10 月時点).

8 ）環境省（2013）東日本大震災の被災地に掞ける放射性物質関 連の環境モニタリング調査：公共用水域, http://www.env.go.jp/ jishin/monitoring/results_r-pw.html (平成 25年 10 月時点).

9 ) 村上道夫 (2013) 大堀川に扔ける放射性セシウム調查一河川中 放射性セシウム負荷の実態調查方法について〜, 第47回日本水 環境学会年会「水環境中放射能に関する研究者の会」研究集会, 配布資料。

10）長尾誠也（2013）河川における放射性物質の動態, 公益社団法 人日本水環境学会平成 24 年度環境研究総合推進費 ZRFb-12T1 放 射性物質の挙動と流出「流域に沈着した放射性物質の移動と消 長に関する文献調查及び知見整理」成果発表会発表資料, http:// www.jswe-nonpoint.com/doc/130318_07nagao.pdf (平成 25年 10 月時 点).

11) Nakamura, K., Yasutaka, T. and Hatakeyama, M. (2012) Concentration of radiocesium in stream water from a mountainous catchment area during rainfall events, Proceedings of International Symposium on Environmental monitoring and dose estimation of residents after accident of TEPCO's Fukushima Daiichi Nuclear Power Station, http://www.rri.kyoto-u.ac.jp/anzen_kiban/outcome/ Proceedings_for_Web/Topics_2-11.pdf (平成 25年 10月時点).

12）文部科学省 (2013) 放射線量等分布マップ拡大サイト, http:// ramap.jaea.go.jp/map/ (平成 25 年 10 月時点).

13）佐藤祐一（2013）流域における放射性物質の動態モデル, 公益 社団法人日本水環境学会平成 24 年度環境研究総合推進費 ZRFb$12 \mathrm{~T} 1$ 放射性物質の挙動と流出「流域に沈着した放射性物質の移 動と消長に関する文献調查及び知見整理」成果発表会発表資料, http://www.jswe-nonpoint.com/doc/130318_08satoh.pdf (平成 25 年 10 月時点).

14）石川百合子, 東海明宏（2006）河川流域における化学物質リス ク評価のための産総研 - 水系暴露解析モデルの開発, 水環境学会 誌, 29, 797-807.

15）独産業技術総合研究所安全科学研究部門 (2013) 産総研-水系 暴露解析モデル, http://www.aist-riss.jp/projects/AIST-SHANEL/ (平 成 25 年 10 月時点).

16）石川百合子, 川口智哉, 東野晴行 (2012) 産総研 - 水系暴露解析 モデル（AIST-SHANEL）による日本全国の1級水系を対象とした 化学物質濃度の推定, 水環境学会誌, 35, 65-72.

17）気象庁 (2013) 気象統計情報, http://www.data.jma.go.jp/gmd/ risk/obsdl/index.php (平成 25 年 10 月時点).

18）国土交通省（2013）水文水質データベース, http://www1.river. $\mathrm{go} . \mathrm{jp} /$ (平成 25 年 10 月時点).

19）恩田裕一（2013）福島原発事故由来の放射性核種の移行調査： データから読み取れる移行の実態と今後, 公益社団法人日本水 環境学会平成 24 年度環境研究総合推進費 ZRFb-12T1 放射性物質 の挙動と流出「流域に沈着した放射性物質の移動と消長に関す 
る文献調查及び知見整理」成果発表会発表資料, http://www.jswenonpoint.com/doc/130318_01onda.pdf (平成 25年 10月時点).

20）古米弘明（2013）研究課題の概要説明, 公益社団法人日本水環 境学会平成 24 年度環境研究総合推進費 ZRFb-12T1 放射性物質 の挙動と流出「流域に沈着した放射性物質の移動と消長に関す る文献調查及び知見整理」成果発表会発表資料, http://www.jswenonpoint.com/doc/130318_02gaiyou.pdf (平成 25年 10 月時点).

21）五十嵐敏文（2013）セシウムの土壤への吸着と移動挙動, 公益 社団法人日本水環境学会平成 24 年度環境研究総合推進費 ZRFb$12 \mathrm{~T} 1$ 放射性物質の挙動と流出「流域に沈着した放射性物質の移 動と消長に関する文献調查及び知見整理」成果発表会発表資料, http://www.jswe-nonpoint.com/doc/130318_03igarashi.pdf (平成 25年 10 月時点).

22) Yasutaka, T., Kawabe, Y., Kurosawa, A. and Komai, T. (2012) Monitoring dissolved radioactive cesium in Abukuma River in Fukushima Prefecture, Proceedings of Environmental monitoring and dose estimation of residents after accident of TEPCO's Fukushima Daiichi Nuclear Power Station, http://www.rri.kyoto-u.ac.jp/anzen_
kiban/outcome/Proceedings_for_Web/Topics_2-17.pdf(平成 25 年 10 月 時点).

23）駒井幸雄, 山田俊郎, 芳賀弘和, 熊谷博史（2013）森林からの 放射性物質の流出, 公益社団法人日本水環境学会平成 24 年度 環境研究総合推進費 ZRFb-12T1 放射性物質の挙動と流出「流 域に沈着した放射性物質の移動と消長に関する文献調查及び 知見整理」成果発表会発表資料, http://www.jswe-nonpoint.com/ doc/130318_04komai.pdf (平成 25 年 10 月時点).

24）福島県, 水質年報 (平成 23 年度).

25）杉山弘信, 角屋睦（1988）唄留関数モデル定数に関する一考察, 農業土木学会論文集, 133, 11-18.

26）藤原洋一 (2004) 進化型計算法による流出モデル定数の多目的 最適化に関する研究, 神戸大学学位論文, 89-102.

27）文部科学省 (2013) (1)第6次航空機モニタリングの測定結果, 及び(2)福島第一原子力発電所から $80 \mathrm{~km}$ 圈外の航空機モニタリ ングの測定結果について, http://radioactivity.nsr.go.jp/ja/conten ts/7000/6749/24/191_258_0301_18.pdf (平成 25年10月時点).

\section{[論 文 要 旨]}

本研究では 2011 年 3 月の福島第一原発事故により放出された放射性セシウムによる河川流域における河 川水濃度と流域土壤に蓄積した量（本論文では, 蓄積量と表記する）の残存状況の推定を目的とした数值シ ミュレーションモデルを構築した。産総研 - 水系暴露解析モデル (AIST-SHANEL) をプラットフォームとし, 流域における懸濁物質の流出ポテンシャルと放射性セシウムの動態を考慮したモデルを導入し，阿武隈川水 系を対象にケーススタディーを実施した。その結果，本モデルの妥当性を検証し，降水による出水に伴う放 射性セシウムの総流出量は僅かであることが示された。特に, セシウム 137 は自然崩壊が少ないことも相まっ て流域における蓄積量を減少させるのは困難なことが考えられ，除染をはじめ総合的な対策を検討すること の必要性が示唆された。本モデルは放射性セシウムの河川流域での挙動解析や污染対策の評価を可能にする ものと考えられる。

キーワード : 分布型モデル；放射性セシウム；河川水濃度；溶存態；懸濁態；蓄積量 ; 阿武隈川 